\title{
LEVEL II SCOUR ANALYSIS FOR BRIDGE 71 (WODSTH00050071) on TOWN HIGHWAY 5, crossing KEDRON BROOK, WOODSTOCK, VERMONT
}

\section{Open-File Report 97-807}

Prepared in cooperation with

VERMONT AGENCY OF TRANSPORTATION

and

FEDERAL HIGHWAY ADMINISTRATION

U.S. Department of the Interior

U.S. Geological Survey

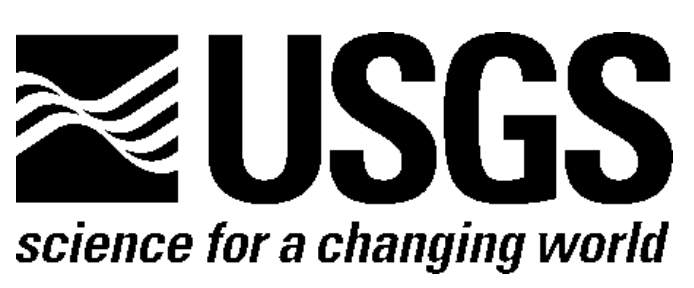


LEVEL II SCOUR ANALYSIS FOR BRIDGE 71 (WODSTH00050071) on TOWN HIGHWAY 5, crossing KEDRON BROOK, WOODSTOCK, VERMONT

By SCOTT A. OLSON and JOSEPH D. AYOTTE

U.S. Geological Survey Open-File Report 97-807

Prepared in cooperation with

VERMONT AGENCY OF TRANSPORTATION and

FEDERAL HIGHWAY ADMINISTRATION 


\title{
U.S. DEPARTMENT OF THE INTERIOR BRUCE BABBITT, Secretary
}

\author{
U.S. GEOLOGICAL SURVEY \\ Mark Schaefer, Acting Director
}

For additional information write to:

District Chief

U.S. Geological Survey 361 Commerce Way

Pembroke, NH 03275-3718
Copies of this report may be purchased from:

U.S. Geological Survey Branch of Information Services Open-File Reports Unit Box 25286

Denver, CO 80225-0286 


\section{CONTENTS}

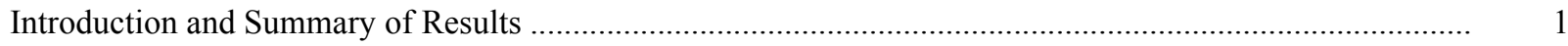

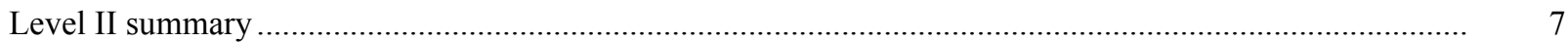

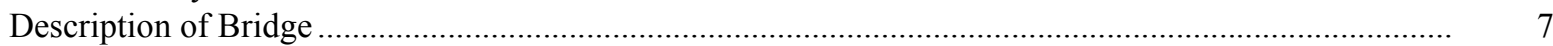

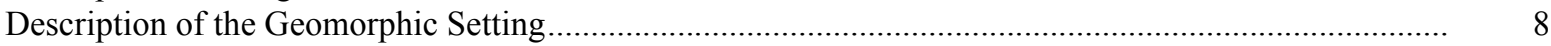

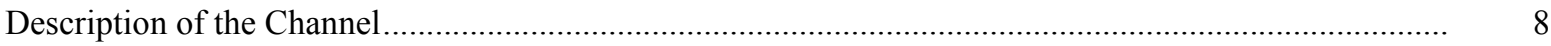

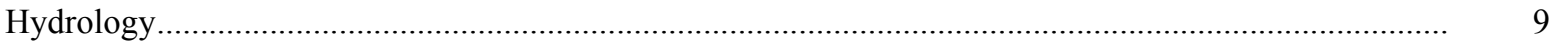

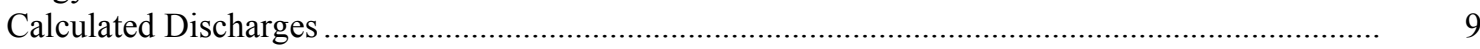

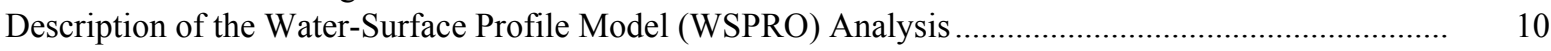

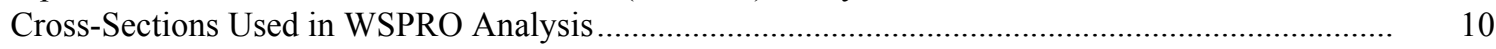

Data and Assumptions Used in WSPRO Model ...................................................................... 11

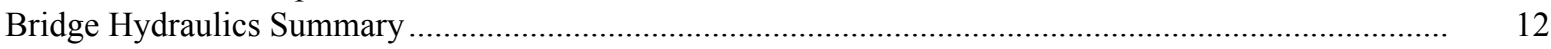

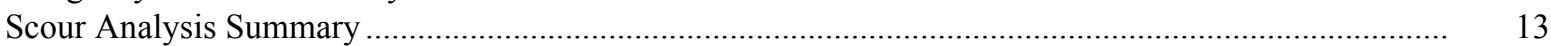

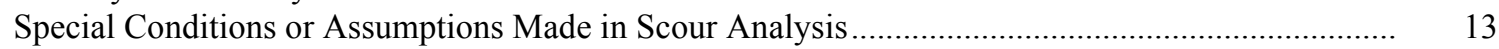

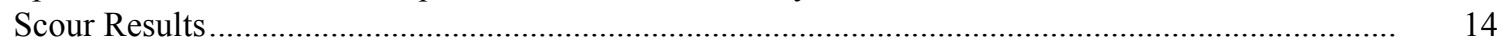

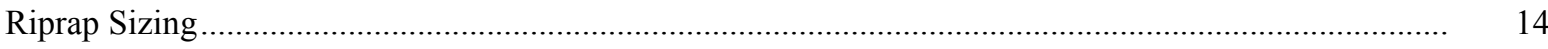

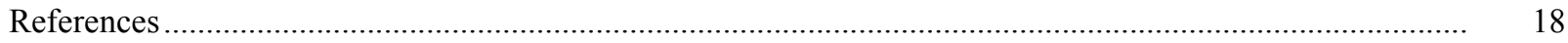

Appendixes:

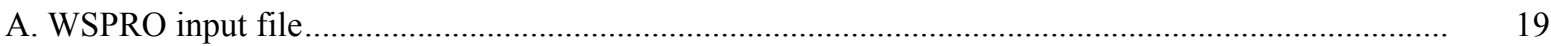

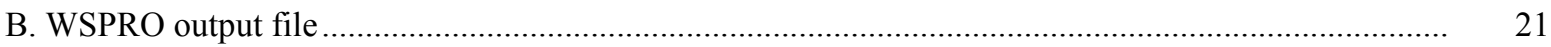

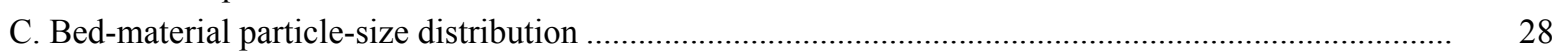

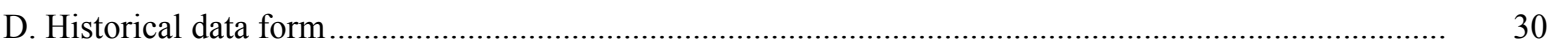

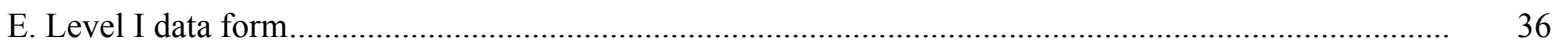

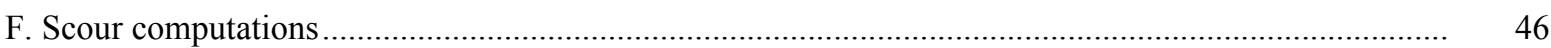

\section{FIGURES}

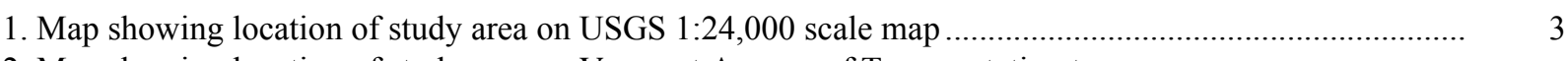

2. Map showing location of study area on Vermont Agency of Transportation town

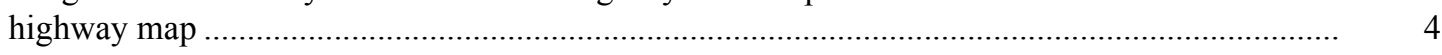

3. Structure WODSTH00050071 viewed from upstream (September 14, 1994) …....................................... 5

4. Downstream channel viewed from structure WODSTH00050071 (September 14, 1994)....................... 5

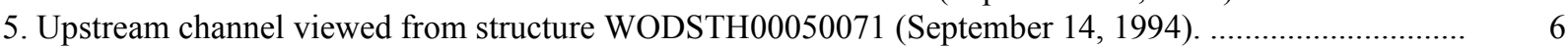

6. Structure WODSTH00050071 viewed from downstream (September 14, 1994).................................. 6

7. Water-surface profiles for the 100- and 500-year discharges at structure

WODSTH00050071 on Town Highway 5, crossing Kedron Brook,

Woodstock, Vermont.

8. Scour elevations for the 100- and 500-year discharges at structure

WODSTH00050071 on Town Highway 5, crossing Kedron Brook,

Woodstock, Vermont. 3

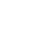

5

6




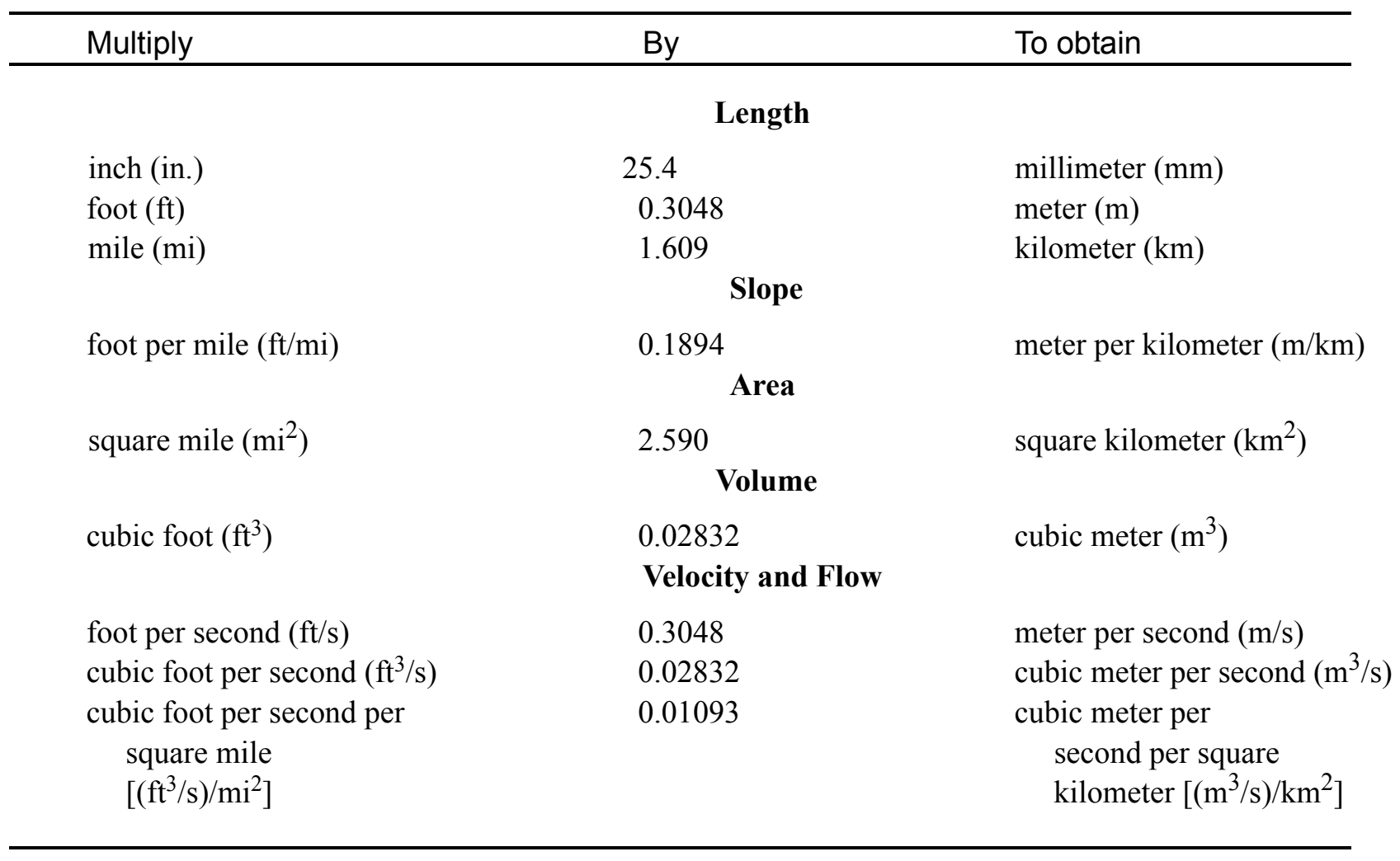

\section{OTHER ABBREVIATIONS}

$\begin{array}{lrlr}\mathrm{BF} & \text { bank full } & \text { LWW } & \text { left wingwall } \\ \mathrm{cfs} & \text { cubic feet per second } & \text { MC } & \text { main channel } \\ \mathrm{D}_{50} & \text { median diameter of bed material } & \text { RAB } & \text { right abutment } \\ \mathrm{DS} & \text { downstream } & \text { RABUT } & \text { face of right abutment } \\ \mathrm{elev} & \text { elevation } & \text { RB } & \text { right bank } \\ \mathrm{f} / \mathrm{p} & \text { flood plain } & \text { ROB } & \text { right overbank } \\ \mathrm{ft}^{2} & \text { square feet } & \text { RWW } & \text { right wingwall } \\ \mathrm{ft} / \mathrm{ft} & \text { feet per foot } & \text { TH } & \text { town highway } \\ \mathrm{JCT} & \text { junction } & \text { UB } & \text { under bridge } \\ \mathrm{LAB} & \text { left abutment } & \text { US } & \text { upstream } \\ \mathrm{LABUT} & \text { face of left abutment } & \text { USGS } & \text { United States Geological Survey } \\ \mathrm{LB} & \text { left bank } & \text { VTAOT Vermont Agency of Transportation } \\ \mathrm{LOB} & \text { left overbank } & \text { WSPRO } & \text { water-surface profile model }\end{array}$

In this report, the words "right" and "left" refer to directions that would be reported by an observer facing downstream. Sea level: In this report, "sea level" refers to the National Geodetic Vertical Datum of 1929-- a geodetic datum derived from a general adjustment of the first-order level nets of the United States and Canada, formerly called Sea Level Datum of 1929.

In the appendices, the above abbreviations may be combined. For example, USLB would represent upstream left bank. 


\title{
LEVEL II SCOUR ANALYSIS FOR BRIDGE 71 (WODSTH00050071) ON TOWN HIGHWAY 5, CROSSING KEDRON BROOK, WOODSTOCK, VERMONT
}

\author{
By Scott A. Olson and Joseph D. Ayotte
}

\section{INTRODUCTION AND SUMMARY OF RESULTS}

This report provides the results of a detailed Level II analysis of scour potential at structure WODSTH00050071 on Town Highway 5 crossing Kedron Brook, Woodstock, Vermont (figures 1-8). A Level II study is a basic engineering analysis of the site, including a quantitative analysis of stream stability and scour (U.S. Department of Transportation, 1993). Results of a Level I scour investigation also are included in Appendix E of this report. A Level I investigation provides a qualitative geomorphic characterization of the study site. Information on the bridge, gleaned from Vermont Agency of Transportation (VTAOT) files, was compiled prior to conducting Level I and Level II analyses and is found in Appendix D.

The site is in the New England Upland section of the New England physiographic province in east-central Vermont. The $16.1-\mathrm{mi}^{2}$ drainage area is in a predominantly rural and forested basin. However, the bridge site is within the Village of Woodstock. In the vicinity of the study site, the surface cover is best described as suburban downstream of the bridge and forest and brush upstream of the bridge.

In the study area, Kedron Brook has an incised, sinuous channel with a slope of approximately $0.03 \mathrm{ft} / \mathrm{ft}$, an average channel top width of $33 \mathrm{ft}$ and an average bank height of $11 \mathrm{ft}$. The predominant channel bed material is cobble with a median grain size $\left(\mathrm{D}_{50}\right)$ of $112 \mathrm{~mm}(0.368 \mathrm{ft})$. The geomorphic assessment at the time of the Level I and Level II site visit on September 14, 1994, indicated that the reach was vertically degraded. Evidence of the degradation was observed at the outlet of the bridge where the stream bed is $4 \mathrm{ft}$ below the downstream invert of the structure (see figure 6).

The Town Highway 5 crossing of Kedron Brook is a 30-ft-long, two-lane bridge/box culvert consisting of one 25-foot concrete span (Vermont Agency of Transportation, written communication, August 3, 1994). The opening length of the structure parallel to the bridge face is $23.5 \mathrm{ft}$. The bridge is supported by vertical, concrete abutments with wingwalls. The channel bed under the bridge is covered entirely by a concrete slab. The channel is skewed approximately 45 degrees to the opening and the opening-skew-to-roadway is also 45 degrees. 
Scour countermeasures at the site include concrete retaining walls on both the left and right downstream banks extending approximately $130 \mathrm{ft}$ downstream; a drywall constructed of stone on the upstream right bank extending to the next bridge upstream; type- 2 stone fill (less than 36 inches diameter) along the upstream left bank, at the upstream end of the upstream right wingwall, and along the base of the retaining wall on the downstream left bank; and type-3 stone-fill (less than 48 inches diameter) along the base of the retaining wall on the downstream right bank. In addition, the channel under the bridge is concrete. Further details describing conditions at the site are included in the Level II Summary and Appendices D and E.

Scour depths and recommended rock rip-rap sizes were computed using the general guidelines described in Hydraulic Engineering Circular 18 (Richardson and others, 1995) for the 100- and 500-year discharges. In addition, the incipient roadway-overtopping discharge is determined and analyzed as another potential worst-case scour scenario. Total scour at a highway crossing is comprised of three components: 1) long-term streambed degradation; 2) contraction scour (due to accelerated flow caused by a reduction in flow area at a bridge) and; 3 ) local scour (caused by accelerated flow around piers and abutments). Total scour is the sum of the three components. Equations are available to compute depths for contraction and local scour and a summary of the results of these computations follows.

Contraction scour for all modelled flows ranged from 0.0 to $2.5 \mathrm{ft}$. The worst-case contraction scour occurred at the incipient roadway-overtopping discharge, which was less than the 100-year discharge. The contraction scour depths do not take the concrete channel bed under the bridge into account. Abutment scour ranged from 8.7 to $18.2 \mathrm{ft}$. The worstcase abutment scour occurred at the 500-year discharge. Additional information on scour depths and depths to armoring are included in the section titled "Scour Results". Scouredstreambed elevations, based on the calculated scour depths, are presented in tables 1 and 2. A cross-section of the scour computed at the bridge is presented in figure 8. Scour depths were calculated assuming an infinite depth of erosive material and a homogeneous particlesize distribution.

It is generally accepted that the Froehlich equation (abutment scour) gives "excessively conservative estimates of scour depths" (Richardson and others, 1995, p. 47). Usually, computed scour depths are evaluated in combination with other information including (but not limited to) historical performance during flood events, the geomorphic stability assessment, existing scour protection measures, and the results of the hydraulic analyses. Therefore, scour depths adopted by VTAOT may differ from the computed values documented herein. 


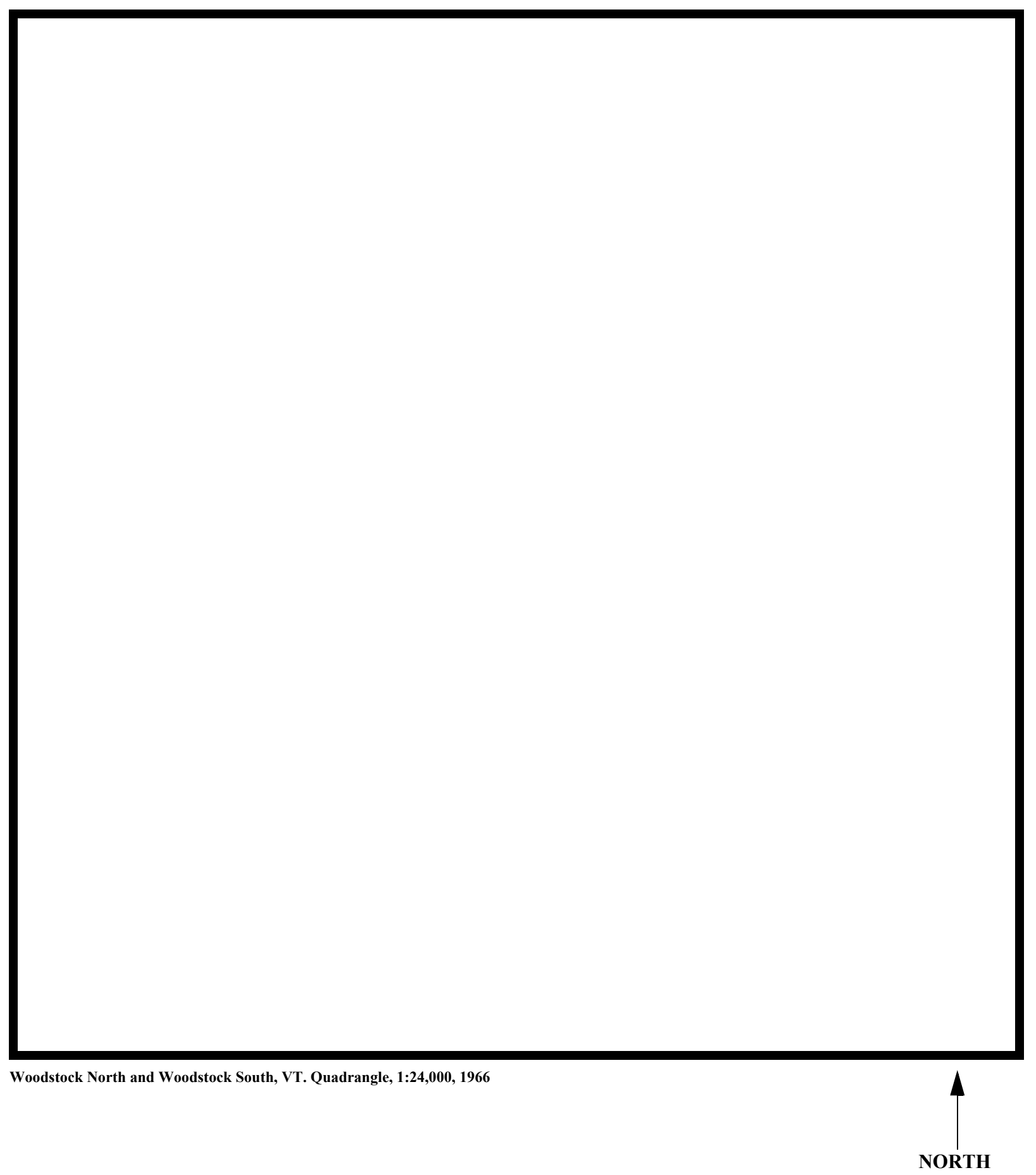

Figure 1. Location of study area on USGS 1:24,000 scale map. 
Figure 2. Location of study area on Vermont Agency of Transportation town highway map. 

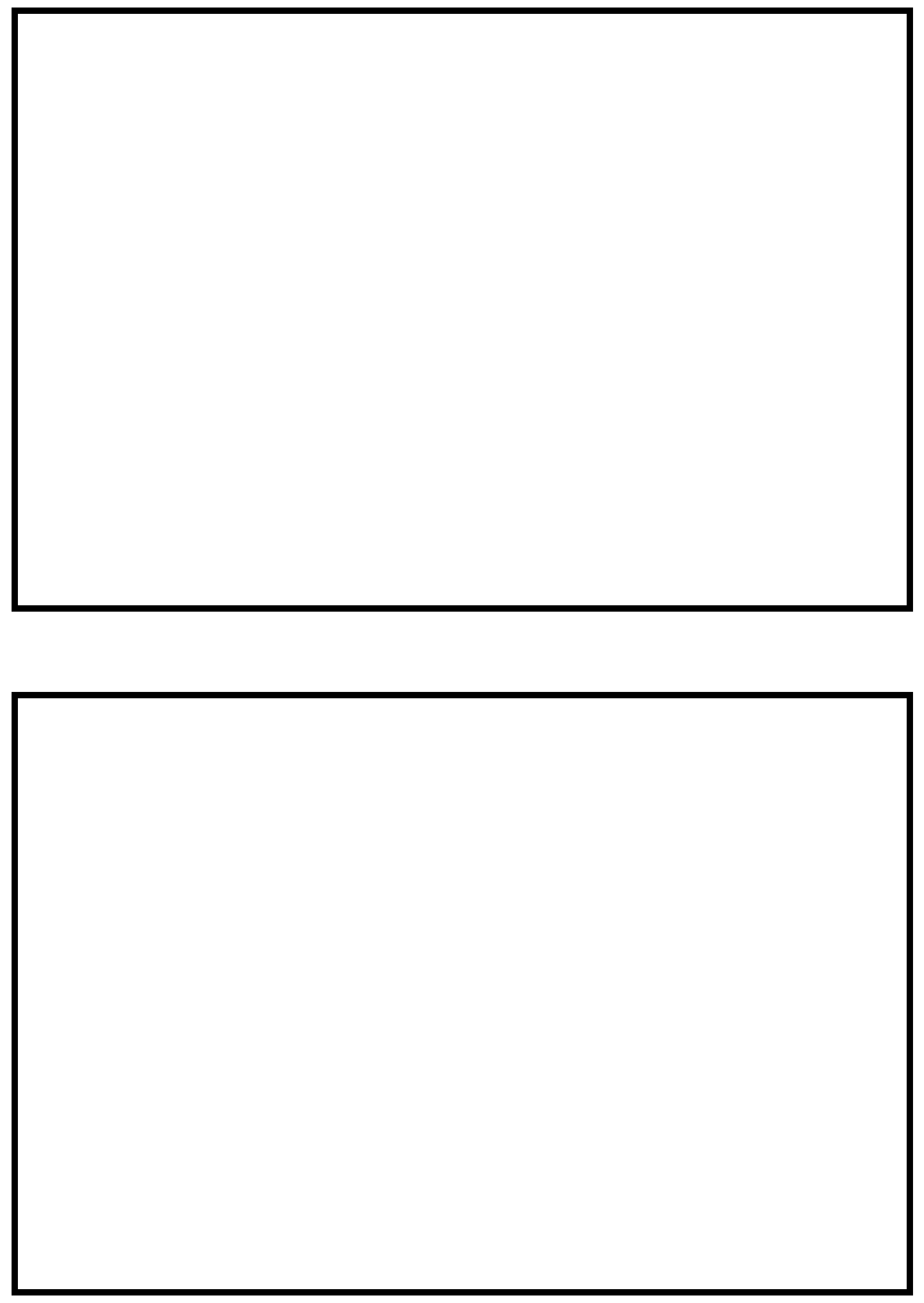

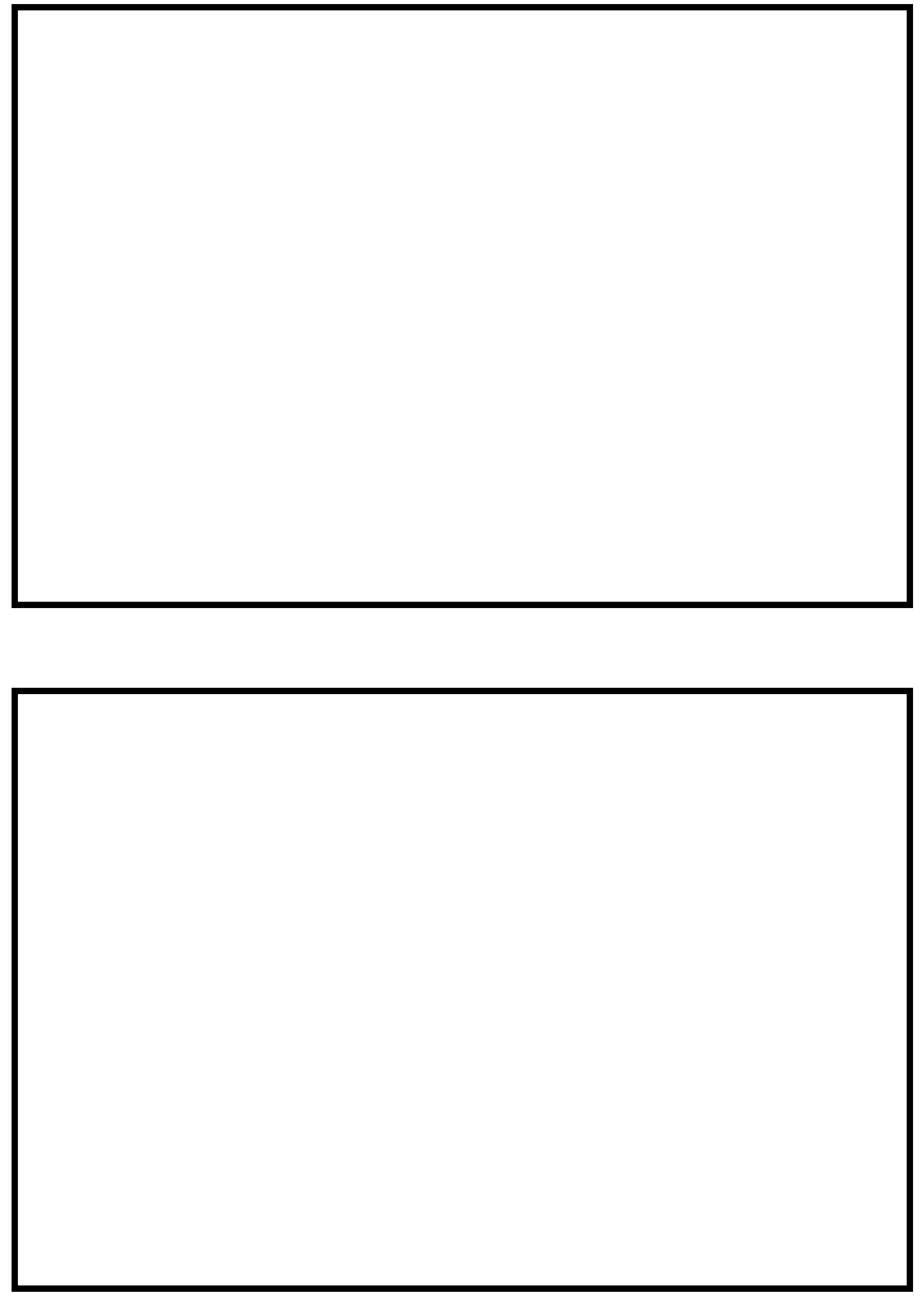


\section{LEVEL II SUMMARY}

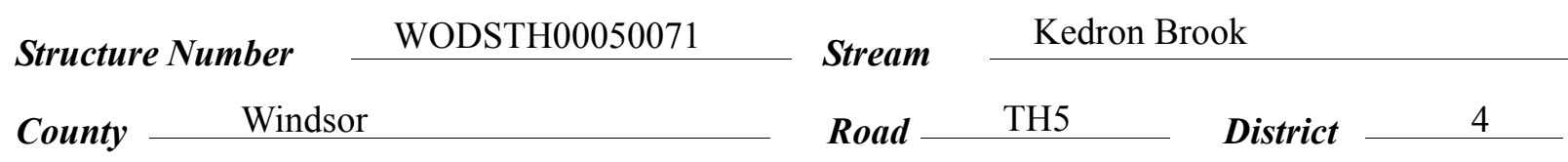

\section{Description of Bridge}

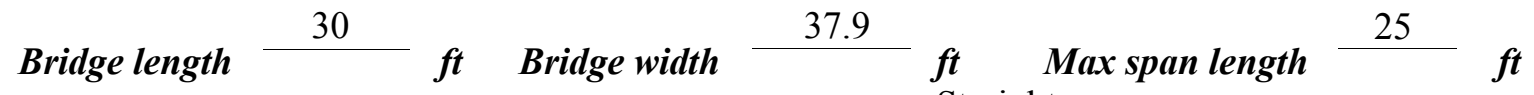
Alignment of bridge to road (on curve or straight)

Abutment type Vertical, concrete

Stone fill on abutment?

$$
\text { No }
$$

\section{Embankment type} Straight

nanamintin... af atan a fill Type-2, along the upstream left bank, at the upstream right wingwall, and along the base of the downstream left retaining wall. Type 3 along the base of the downstream right retaining wall.

Abutments are concrete. The channel under the bridge is also concrete

\section{$\mathrm{Y}$}

Is bridge skewed to flood flow according to $\mathrm{Y} \quad$ ' survey? Angle

There is a severe channel bend near the upstream bridge face. The bend results in an impact zone and scour at the upstream left wingwall.

Debris accumulation on bridge at time of Level I or Level II site visit:

\begin{tabular}{|c|c|c|c|}
\hline & $\begin{array}{c}\text { Date of insnortion } \\
\underline{9 / 14 / 94}\end{array}$ & $\begin{array}{l}\text { Percent of almmual } \\
\text { blocked inortzontatly }\end{array}$ & $\begin{array}{l}\text { Percent of } 0 \\
\text { blocked verticatty }\end{array}$ \\
\hline Level I & $9 / 14 / 94$ & 0 & 0 \\
\hline el II & Low. & & \\
\hline
\end{tabular}

\section{Potential for debris}

September 14, 1994. Kedron Brook enters the Ottauquechee River approximately $600 \mathrm{ft}$ Doscriho anv, foaturos noar ar at tho hridoo that mav, affort flow, (includo ahsorvation datol downstream of this bridge site. However, there is no backwater from the Ottauquechee River at this bridge site (Federal Emergency Management Agency, 1979). 


\section{Description of the Geomorphic Setting}

General topography The channel is located within a high terrace of the Ottauquechee River

Valley.

Geomorphic conditions at bridge site: downstream (DS), upstream (US)

Date of inspection $\quad 9 / 14 / 94$

DS left: $\quad$ Steep channel bank to a wide flood plain.

DS right: $\quad$ Steep channel bank to a wide flood plain.

US left: $\quad$ Steep channel bank to a wide flood plain.

US right: $\quad$ Steep channel bank to a wide flood plain.

\section{Description of the Channel}

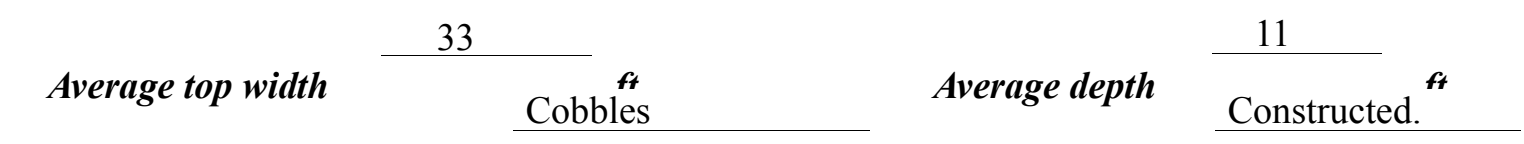

Predominant bed material

Bank material

Incised, sinuous but

stable, with constructed channel boundaries and a

$9 / 14 / 94$

Vegetative co ${ }^{1}$ A few trees on the immediate bank, otherwise grass.

DS left: $\quad$ Trees and brush on immediate bank with grass on the overbank.

DS right: $\quad$ Trees.

US left: $\quad$ Brush and a few trees on the immediate bank with grass on the overbank.

US right:

$\mathrm{Y}$

Do banks appear stable? There is a 4- to 5-ft scour hole at the location where flow spills off the concrete bottom of the box culvert.
date of observation.

None. September 14,

1994.

Describe any obstructions in channel and date of observation. 


\section{Hydrology}

Drainage area $\frac{16.1}{m i^{2}}$

Percentage of drainage area in physiographic provinces: (approximate)

Physiographic province/section New England/New England Upland
Percent of drainage area 100

Is drainage area considered rural or urban? Rural Describe any significant urbanization:

The bridge site is within the Village of Woodstock. However, the drainage is considered rural.

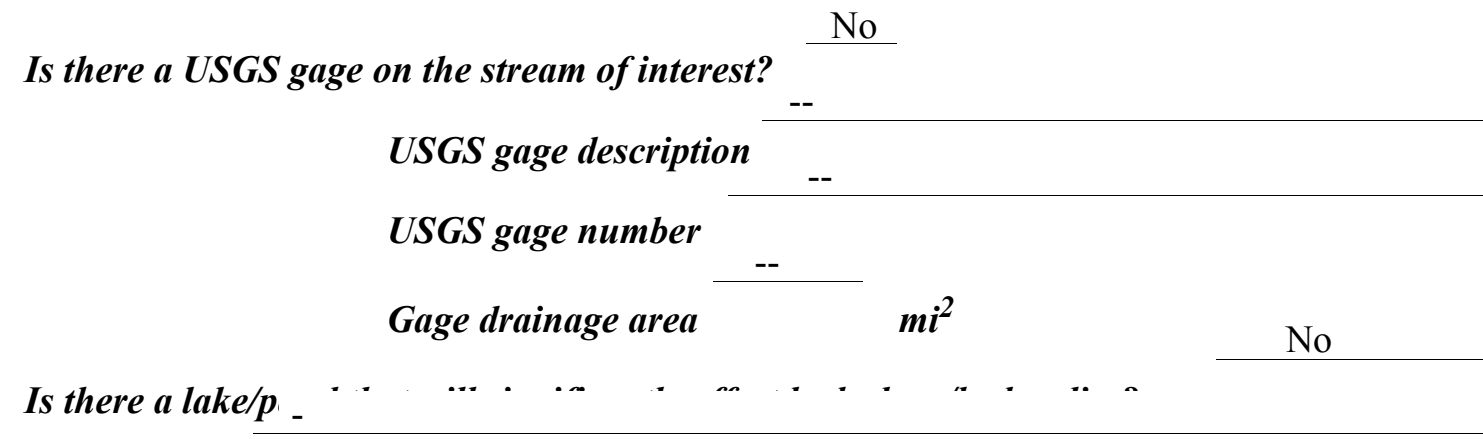

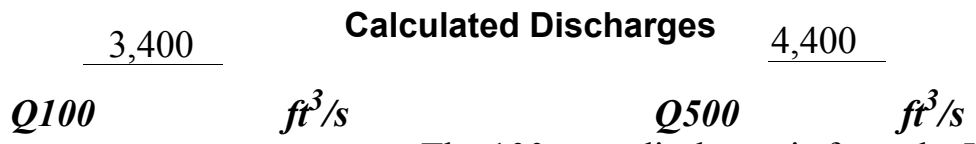

The 100-year discharge is from the VTAOT

database (VTAOT, written communication, May, 1995). The 500-year discharge was determined by graphical extrapolation of the flood frequency estimates available in the VTAOT database.

The discharges were within a range defined by the results of several empirical methods for determining flood frequency estimates for ungaged sites (Benson, 1962; Johnson and Tasker, 1974; FHWA, 1983; Potter, 1957a\&b; Talbot, 1887). 


\section{Description of the Water-Surface Profile Model (WSPRO) Analysis}

Datum for WSPRO analysis (USGS survey, sea level, VTAOT plans)

USGS survey

Datum tie between USGS survey and VTAOT plans

Subtract 400.3 from USGS

arbitrary survey datum to obtain plans' datum.

Description of reference marks used to determine USGS datum. $\quad$ RM1 is a chiseled X

within a chiseled square on top of the upstream end of the right abutment (elev.

$499.75 \mathrm{ft}$, arbitrary survey datum).

\section{Cross-Sections Used in WSPRO Analysis}

\begin{tabular}{cccl}
\hline${ }^{1}$ Cross-section & $\begin{array}{c}\text { Section } \\
\text { Reference } \\
\text { Distance } \\
\text { (SRD) } \text { in feet }\end{array}$ & $\begin{array}{c}{ }^{2} \text { Cross-section } \\
\text { development }\end{array}$ & \multicolumn{1}{c}{ Comments } \\
\hline EXIT2 & -127 & 1 & Downstream section \\
EXIT1 & -53 & 1 & Exit section \\
FULLV & 0 & 2 & $\begin{array}{l}\text { Downstream Full-valley } \\
\text { section (Templated from } \\
\text { EXIT1) }\end{array}$ \\
BRIDG & 0 & 1 & Bridge section \\
RDWAY & 28 & 1 & Road Grade section \\
APPRO & 73 & 1 & Approach section. \\
\hline
\end{tabular}

${ }^{1}$ For location of cross-sections see plan-view sketch included with Level I field form, Appendix E. For more detail on how cross-sections were developed see WSPRO input file. 


\section{Data and Assumptions Used in WSPRO Model}

Hydraulic analyses of the reach were done by use of the Federal Highway Administration's WSPRO step-backwater computer program (Shearman and others, 1986, and Shearman, 1990). The analyses reported herein reflect conditions existing at the site at the time of the study. Furthermore, in the development of the model it was necessary to assume no accumulation of debris or ice at the site. Results of the hydraulic model are presented in the Bridge Hydraulic Summary, Appendix B, and figure 7.

Channel roughness factors (Manning's " $n$ ") used in the hydraulic model were estimated using field inspections at each cross section following the general guidelines described by Arcement and Schneider (1989). Final adjustments to the values were made during the modelling of the reach. Channel " $n$ " values for the reach ranged from 0.020 to 0.055 , and overbank " $n$ " values ranged from 0.035 to 0.070 .

Normal depth at the exit section (EXIT2) was assumed as the starting water surface for the 100-year and incipient roadway-overtopping discharges. This depth was computed by use of the slope-conveyance method outlined in the user's manual for WSPRO (Shearman, 1990). The slope used was $0.032 \mathrm{ft} / \mathrm{ft}$, which was estimated from the topographic map (U.S. Geological Survey, 1966). For the 500-year model, this energy gradient resulted in a normal depth which was approximately $0.4 \mathrm{ft}$ below critical depth. Thus, critical depth at the exit was allowed for this discharge.

The surveyed approach section (APPRO) was surveyed one bridge length upstream of the upstream face as recommended by Shearman and others (1986). This location also provides a consistent method for determining scour variables.

For the incipient-overtopping discharge, WSPRO assumes critical depth at the bridge section. A supercritical model was developed for this discharge. After analyzing both the supercritical and subcritical profiles, it can be determined that the water-surface profile does

pass through critical depth within the bridge opening. Thus, the assumption of critical depth at the bridge is a satisfactory solution. 


\section{Bridge Hydraulics Summary}

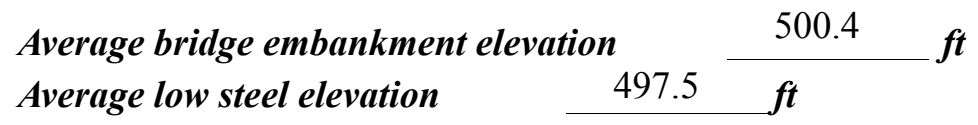

$$
\text { 100-year discharge } \quad 3,400 \quad \mathrm{ft}^{3} / \mathrm{s}
$$

Water-surface elevation in bridge opening $\quad 497.5 \quad f t$

Road overtopping? ___ Y Discharge over road _ $\quad \begin{array}{llll}730 & \mathrm{ft}^{3} / \mathrm{s}\end{array}$

Area of flow in bridge opening $\quad 228 \quad \mathrm{ft}^{2}$

Average velocity in bridge opening $11.6 \quad \mathrm{ft} / \mathrm{s}$

$\begin{array}{llll}\text { Maximum WSPRO tube velocity at bridge } & 17.2 \mathrm{ft} / \mathrm{s}\end{array}$

Water-surface elevation at Approach section with bridge 501.4

Water-surface elevation at Approach section without bridge $\quad \overline{492.7}$

Amount of backwater caused by bridge $\quad 8.7 \quad$ it

500-year discharge $\quad 4,400 \quad \boldsymbol{f t}^{3} / \mathrm{s}$

Water-surface elevation in bridge opening $\quad 497.5 \mathrm{ft}$

$\begin{array}{llll}\text { Road overtopping? ___ Y Discharge over road __ } 1,590 & \mathrm{ft}^{3} / \mathrm{s}\end{array}$

Area of flow in bridge opening $\quad 229 \quad \mathrm{ft}^{2}$

Average velocity in bridge opening $\quad 12.1 \mathrm{ft} / \mathrm{s}$

Maximum WSPRO tube velocity at bridge 15.8 's

Water-surface elevation at Approach section with bridge 501.9

Water-surface elevation at Approach section without bridge $\quad 494.8$

Amount of backwater caused by bridge $\quad 7.1$.t

Incipient overtopping discharge $\quad 2,500 \mathrm{ft}^{3} / \mathrm{s}$

Water-surface elevation in bridge opening $492.6 \quad t$

Area of flow in bridge opening $\quad 148 \quad \mathrm{ft}^{2}$

Average velocity in bridge opening $\quad 16.9 \quad \mathrm{ft} / \mathrm{s}$

Maximum WSPRO tube velocity at bridge $\quad 22.9 \mathrm{ft} / \mathrm{s}$

Water-surface elevation at Approach section with bridge

Water-surface elevation at Approach section without bridge

497.5

Amount of backwater caused by bridge $\quad 5.6$, t

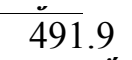




\section{Scour Analysis Summary}

\section{Special Conditions or Assumptions Made in Scour Analysis}

Scour depths were computed using the general guidelines described in Hydraulic Engineering Circular 18 (Richardson and others, 1995). Scour depths were calculated assuming an infinite depth of erosive material and a homogeneous particle-size distribution. The results of the scour analysis are presented in tables 1 and 2 and a graph of the scour depths is presented in figure 8 .

Contraction scour for the incipient roadway-overtopping discharge was computed by use of the Laursen clear-water contraction scour equation (Richardson and others, 1995, p. 32 , equation 20). At this site, the 100- and 500-yr discharges resulted in unsubmerged orifice flow. Contraction scour at bridges with orifice flow is best estimated by use of the Chang pressure-flow scour equation (oral communication, J. Sterling Jones, October 4, 1996). Thus, contraction scour for these discharges was computed by use of the Chang equation (Richardson and others, 1995, p. 145-146). At this site, the scour computations do not take into account the constructed channel bed.

For comparison, contraction scour for the discharges resulting in orifice flow was also computed by use of the Laursen clear-water contraction scour equation and the Umbrell pressure-flow equation (Richardson and others, 1995, p. 144) and presented in Appendix F. Furthermore, for those discharges resulting in unsubmerged orifice flow, contraction scour was computed by substituting estimates for the depth of flow at the downstream bridge face in the contraction scour equations. Results with respect to these substitutions are provided in Appendix F.

Abutment scour was computed by use of the Froehlich equation (Richardson and others, 1995, p. 48, equation 28). Variables for the Froehlich equation include the Froude number of the flow approaching the embankments, the length of the embankment blocking flow, and the depth of flow approaching the embankment less any roadway overtopping. 


\section{Scour Results}

$$
\text { 100-yr discharge 500-yrdischarge }
$$

Contraction scour:

(Scour depths in feet)

Main channel

Live-bed scour

Clear-water scour

Depth to armoring

Left overbank

Right overbank

Local scour:

Abutment scour

Left abutment

16.5

18.2

17.9

$10.5-$

12.8

8.7-

\section{Right abutment}

Pier scour

Pier 1

Pier 2

Pier 3

Abutments:

Left abutment

Right abutment

Piers:

Pier 1

Pier 2

overtopping discharge 


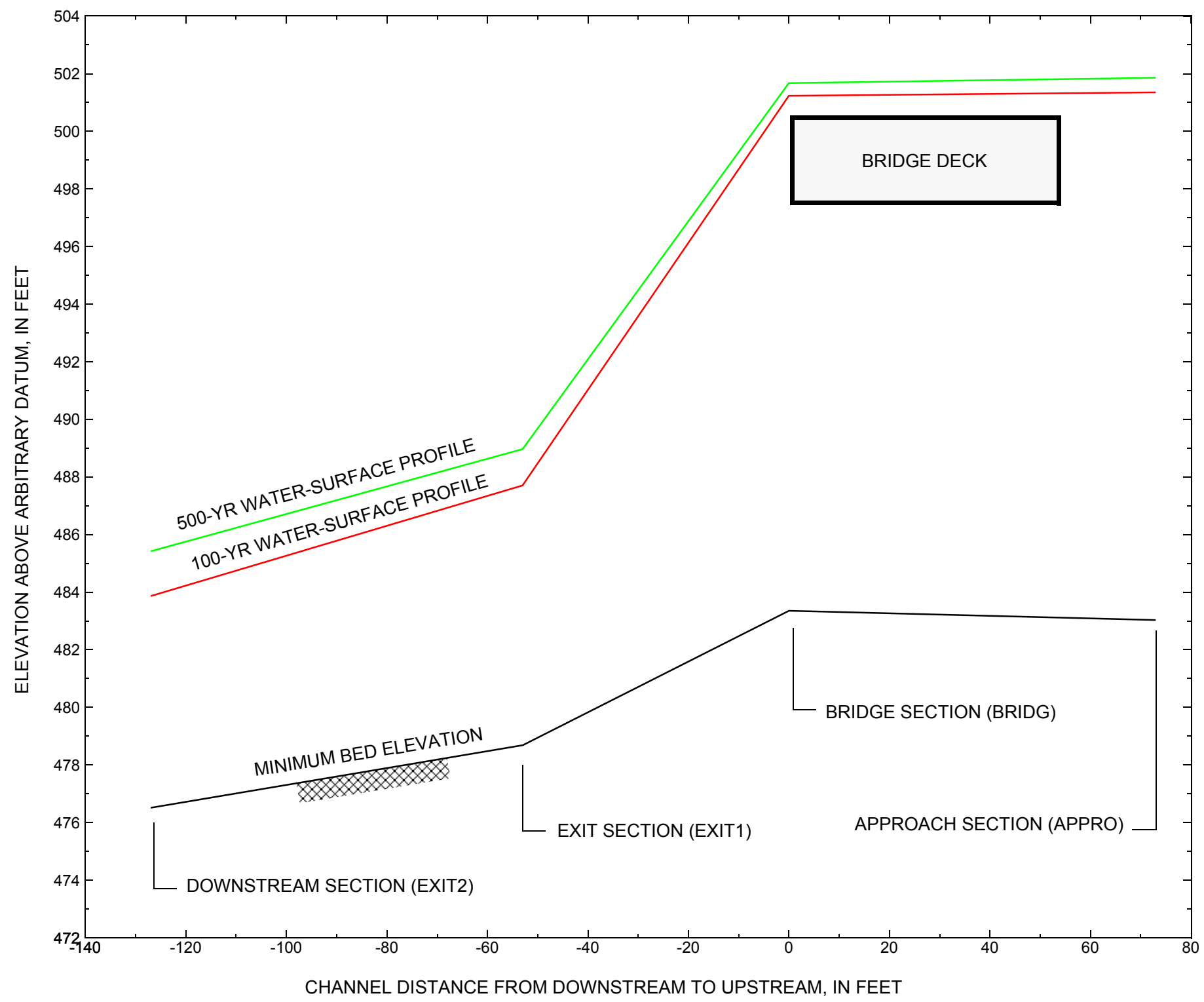

Figure 7. Water-surface profiles for the 100- and 500-yr discharges at structure WODSTH00050071 on Town Highway 5, crossing Kedron Brook, Woodstock, Vermont. 


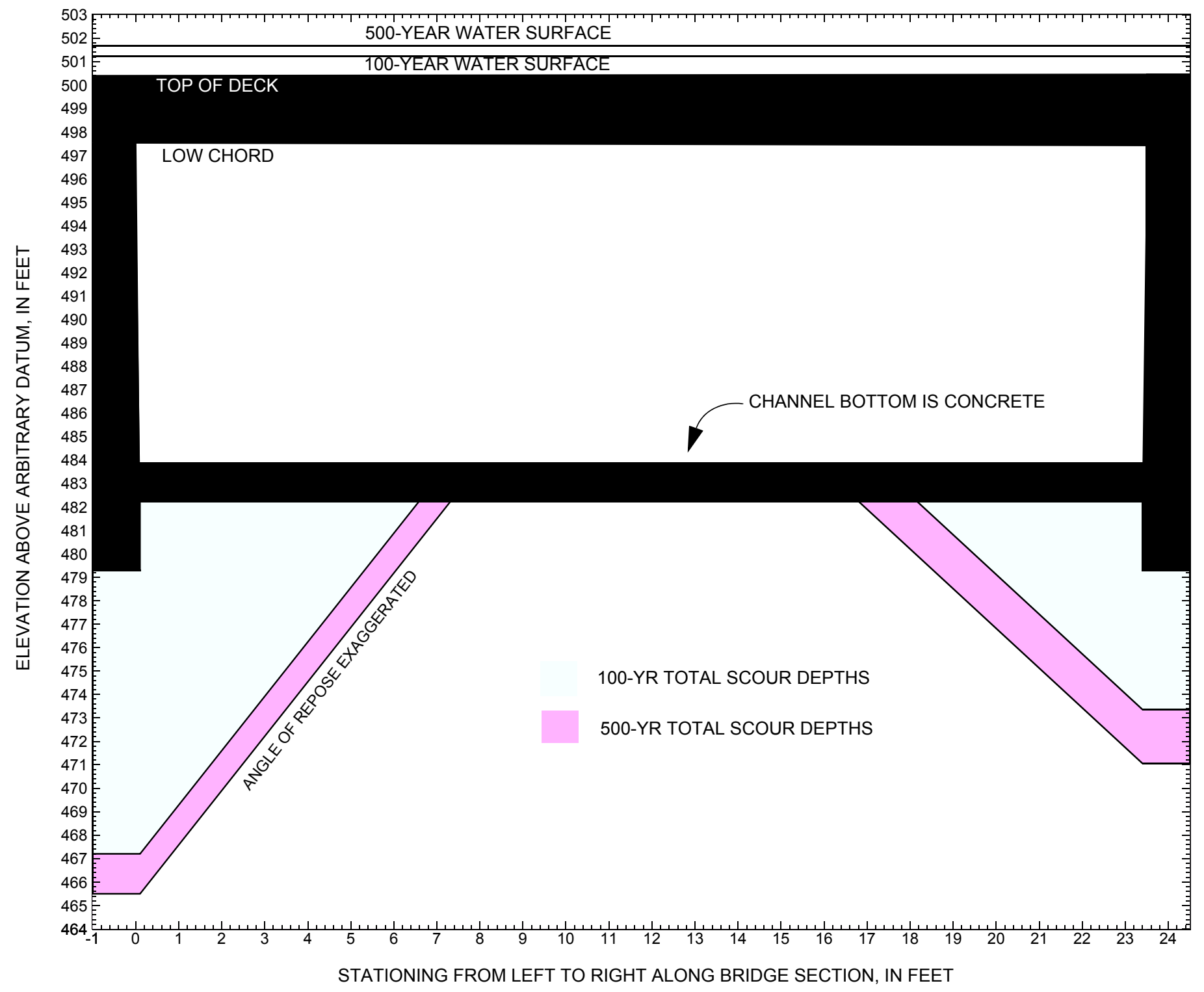

Figure 8. Scour elevations for the 100-yr and 500-yr discharges at structure WODSTH00050071 on Town Highway 5, crossing Kedron Brook, Woodstock, Vermont. 
Table 1. Remaining footing/pile depth at abutments for the 100-year discharge at structure WODSTH00050071 on Town Highway 5, crossing Kedron Brook, Woodstock, Vermont.

[VTAOT, Vermont Agency of Transportation; --,no data]

\begin{tabular}{|c|c|c|c|c|c|c|c|c|c|c|c|}
\hline Description & Station $^{1}$ & $\begin{array}{l}\text { VTAOT } \\
\text { minimum } \\
\text { low-chord } \\
\text { elevation } \\
\text { (feet) }\end{array}$ & $\begin{array}{l}\text { Surveyed } \\
\text { minimum } \\
\text { low-chord } \\
\text { elevation } \\
\quad \text { (feet) }\end{array}$ & $\begin{array}{c}\text { Bottom of } \\
\text { footing/pile } \\
\text { elevation }{ }^{2} \\
\text { (feet) }\end{array}$ & $\begin{array}{c}\text { Channel } \\
\text { elevation at } \\
\text { abutment/ } \\
\text { pier }^{2} \\
\text { (feet) }\end{array}$ & $\begin{array}{l}\text { Contraction } \\
\text { scour depth } \\
\text { (feet) }\end{array}$ & $\begin{array}{l}\text { Abutment } \\
\text { scour } \\
\text { depth } \\
\text { (feet) }\end{array}$ & $\begin{array}{l}\text { Pier } \\
\text { scour } \\
\text { depth } \\
\text { (feet) }\end{array}$ & $\begin{array}{l}\text { Depth of } \\
\text { total scour } \\
\text { (feet) }\end{array}$ & $\begin{array}{c}\text { Elevation of } \\
\text { scour }^{2} \\
\text { (feet) }\end{array}$ & $\begin{array}{c}\text { Remaining } \\
\text { footing/pile } \\
\text { depth } \\
\text { (feet) }\end{array}$ \\
\hline \multicolumn{12}{|c|}{100 -yr. discharge is 3,400 cubic-feet per second } \\
\hline Left abutment & 0.0 & 97.2 & 497.5 & 479.3 & 483.7 & 0.0 & 16.5 & -- & 16.5 & 467.2 & -12.1 \\
\hline Right abutment & 23.5 & 97.1 & 497.4 & 479.3 & 483.9 & 0.0 & 10.5 & -- & 10.5 & 473.4 & -5.9 \\
\hline
\end{tabular}

1.Measured along the face of the most constricting side of the bridge.

2.Arbitrary datum for this study.

Table 2. Remaining footing/pile depth at abutments for the 500-year discharge at structure WODSTH00050071 on Town Highway 5, crossing Kedron Brook, Woodstock, Vermont.

[VTAOT, Vermont Agency of Transportation; --, no data]

\begin{tabular}{|c|c|c|c|c|c|c|c|c|c|c|c|}
\hline Description & Station $^{1}$ & $\begin{array}{l}\text { VTAOT } \\
\text { minimum } \\
\text { low-chord } \\
\text { elevation } \\
\text { (feet) }\end{array}$ & $\begin{array}{c}\text { Surveyed } \\
\text { minimum } \\
\text { low-chord } \\
\text { elevation } \\
\text { (feet) }\end{array}$ & $\begin{array}{c}\text { Bottom of } \\
\text { footing/pile } \\
\text { elevation } \\
\text { (feet) }\end{array}$ & $\begin{array}{c}\text { Channel } \\
\text { elevation at } \\
\text { abutment/ } \\
\text { pier }^{2} \\
\text { (feet) }\end{array}$ & $\begin{array}{l}\text { Contraction } \\
\text { scour depth } \\
\text { (feet) }\end{array}$ & $\begin{array}{c}\text { Abutment } \\
\text { scour } \\
\text { depth } \\
\text { (feet) }\end{array}$ & $\begin{array}{l}\text { Pier } \\
\text { scour } \\
\text { depth } \\
\text { (feet) }\end{array}$ & $\begin{array}{l}\text { Depth of } \\
\text { total scour } \\
\text { (feet) }\end{array}$ & $\begin{array}{c}\text { Elevation of } \\
\text { scour }^{2} \\
\text { (feet) }\end{array}$ & $\begin{array}{c}\text { Remaining } \\
\text { footing/pile } \\
\text { depth } \\
\text { (feet) }\end{array}$ \\
\hline \multicolumn{12}{|c|}{500 -yr. discharge is 4,400 cubic-feet per second } \\
\hline Left abutment & 0.0 & 97.2 & 497.5 & 479.3 & 483.7 & 0.0 & 18.2 & -- & 18.2 & 465.5 & -13.8 \\
\hline Right abutment & 23.5 & 97.1 & 497.4 & 479.3 & 483.9 & 0.0 & 12.8 & -- & 12.8 & 471.1 & -8.2 \\
\hline
\end{tabular}

1.Measured along the face of the most constricting side of the bridge.

2.Arbitrary datum for this study. 


\section{SELECTED REFERENCES}

Arcement, G.J., Jr., and Schneider, V.R., 1989, Guide for selecting Manning's roughness coefficients for natural channels and flood plains: U.S. Geological Survey Water-Supply Paper 2339, 38 p.

Barnes, H.H., Jr., 1967, Roughness characteristics of natural channels: U.S. Geological Survey Water-Supply Paper 1849,213 p.

Benson, M. A., 1962, Factors Influencing the Occurrence of Floods in a Humid Region of Diverse Terrain: U.S. Geological Survey WaterSupply Paper 1580-B, 64 p.

Brown, S.A. and Clyde, E.S., 1989, Design of riprap revetment: Federal Highway Administration Hydraulic Engineering Circular No. 11, Publication FHWA-IP-89-016, 156 p.

Federal Highway Administration, 1983, Runoff estimates for small watersheds and development of sound design: Federal Highway Administration Report FHWA-RD-77-158.

Federal Highway Administration, 1993, Stream Stability and Scour at Highway Bridges: Participant Workbook: Federal Highway Administration Report FHWA-HI-91-011.

Federal Emergency Management Agency, 1979, Flood Insurance Study, Town of Woodstock, Windsor County, Vermont: Washington, D.C., September, 1979.

Froehlich, D.C., 1989, Local scour at bridge abutments in Ports, M.A., ed., Hydraulic Engineering--Proceedings of the 1989 National Conference on Hydraulic Engineering: New York, American Society of Civil Engineers, p. 13-18.

Hayes, D.C.,1993, Site selection and collection of bridge-scour data in Delaware, Maryland, and Virginia: U.S. Geological Survey WaterResources Investigation Report 93-4017, 23 p.

Johnson, C.G. and Tasker, G.D.,1974, Progress report on flood magnitude and frequency of Vermont streams: U.S. Geological Survey OpenFile Report 74-130, 37 p.

Lagasse, P.F., Schall, J.D., Johnson, F., Richardson, E.V., Chang, F., 1995, Stream Stability at Highway Structures: Federal Highway Administration Hydraulic Engineering Circular No. 20, Publication FHWA-IP-90-014, 144 p.

Laursen, E.M., 1960, Scour at bridge crossings: Journal of the Hydraulics Division, American Society of Civil Engineers, v. 86, no. HY2, p. 39-53.

Potter, W. D., 1957a, Peak rates of runoff in the Adirondack, White Mountains, and Maine woods area, Bureau of Public Roads

Potter, W. D., 1957b, Peak rates of runoff in the New England Hill and Lowland area, Bureau of Public Roads

Richardson, E.V. and Davis, S.R., 1995, Evaluating scour at bridges: Federal Highway Administration Hydraulic Engineering Circular No. 18, Publication FHWA-IP-90-017, 204 p.

Richardson, E.V., Simons, D.B., and Julien, P.Y., 1990, Highways in the river environment: Federal Highway Administration Publication FHWA-HI-90-016.

Ritter, D.F., 1984, Process Geomorphology: W.C. Brown Co., Debuque, Iowa, 603 p.

Shearman, J.O., 1990, User's manual for WSPRO--a computer model for water surface profile computations: Federal Highway Administration Publication FHWA-IP-89-027, 187 p.

Shearman, J.O., Kirby, W.H., Schneider, V.R., and Flippo, H.N., 1986, Bridge waterways analysis model; research report: Federal Highway Administration Publication FHWA-RD-86-108, 112 p.

Talbot, A.N., 1887, The determination of water-way for bridges and culverts.

U.S. Department of Transportation, 1993, Stream stability and scour at highway bridges, Participant Workbook: Federal Highway Administration Publication FHWA HI-91-011.

U.S. Geological Survey, 1966, Woodstock North, Vermont 7.5 Minute Series quadrangle map: U.S. Geological Survey Topographic Maps, Scale 1:24,000.

U.S. Geological Survey, 1966, Woodstock South, Vermont 7.5 Minute Series quadrangle map: U.S. Geological Survey Topographic Maps, Scale 1:24,000. 


\section{APPENDIX A: \\ WSPRO INPUT FILE}




\section{WSPRO INPUT FILE}

GR

$\mathrm{N}$

SA

*

GR

$\mathrm{N}$

SA

*

XS

$\mathrm{BR}$

GR

GR

$\mathrm{N}$

CD

*

$\mathrm{XR}$

GR

GR

GR

AS

GR

GR

GR

GR

$\mathrm{N}$

SA

HP 1 BRIDG

HP 2 BRIDG

HP 1 BRIDG

HP 2 RDWAY

$\mathrm{HP} 1 \mathrm{APPRO}$

HP 2 APPRO

HP 1 BRIDG

HP 2 BRIDG

HP 1 BRIDG

HP 2 RDWAY

U.S. Geological Survey WSPRO Input File wods071.wsp

Hydraulic analysis for structure WODSTH00050071 Date: 17-JUN-97 HYDRAULIC ANALYSIS OF BRIDGE 71 IN WOODSTOCK, VT OVER KEDRON BROOK

$62930 \quad 552553551516 \quad 17 \quad 13 \quad 3 * \begin{array}{llllllllll}15 & 14 & 23 & 21 & 11 & 12 & 4 & 7 & 3\end{array}$

$3400 \quad 4400 \quad 2500$

$0.0320 .032 \quad 0.032$

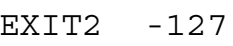

0.0

36.8

Left ends of EXIT1 and EXIT2 were extended based upon the Flood Insurance Study Model.

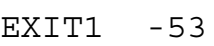




\section{APPENDIX B: \\ WSPRO OUTPUT FILE}




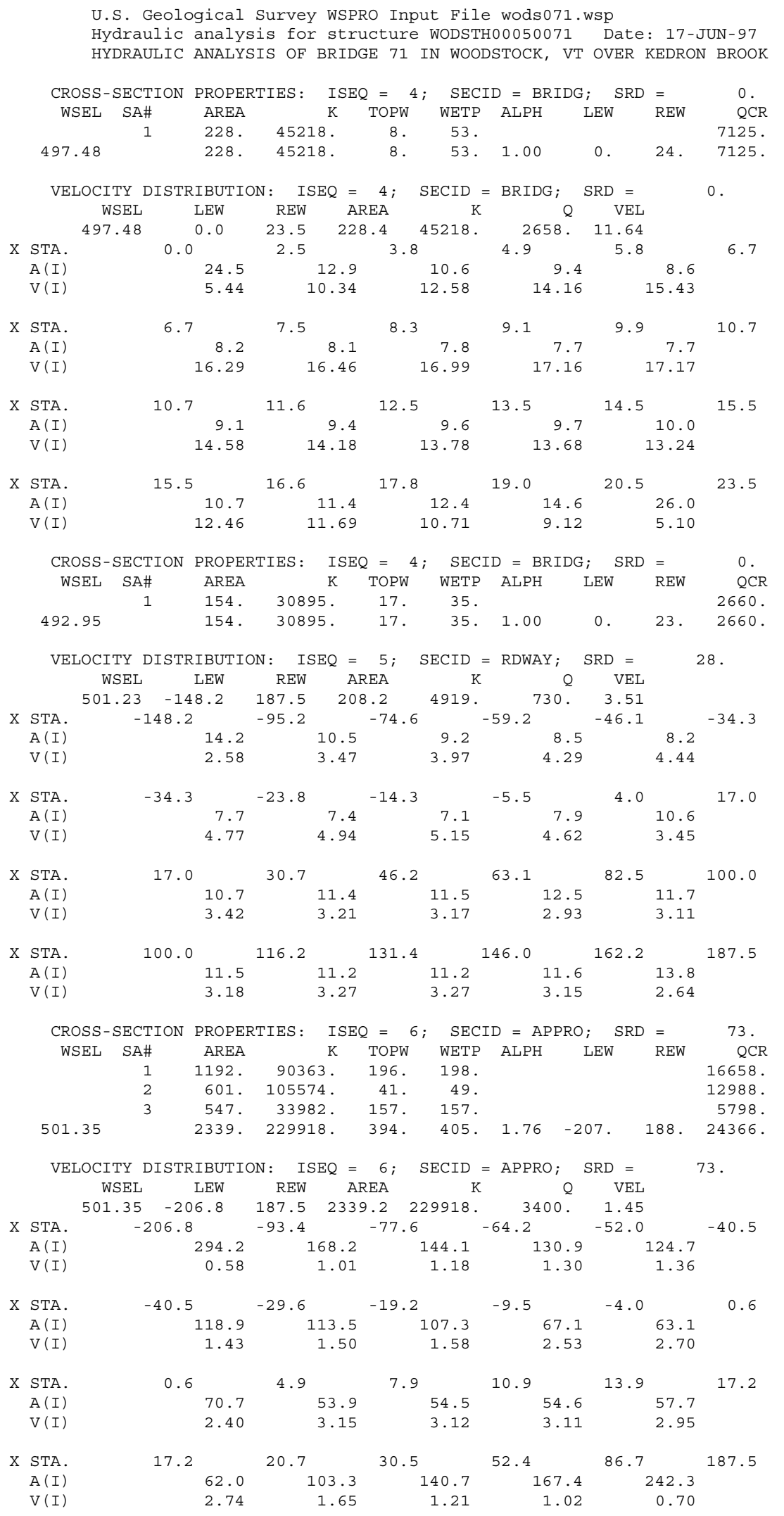




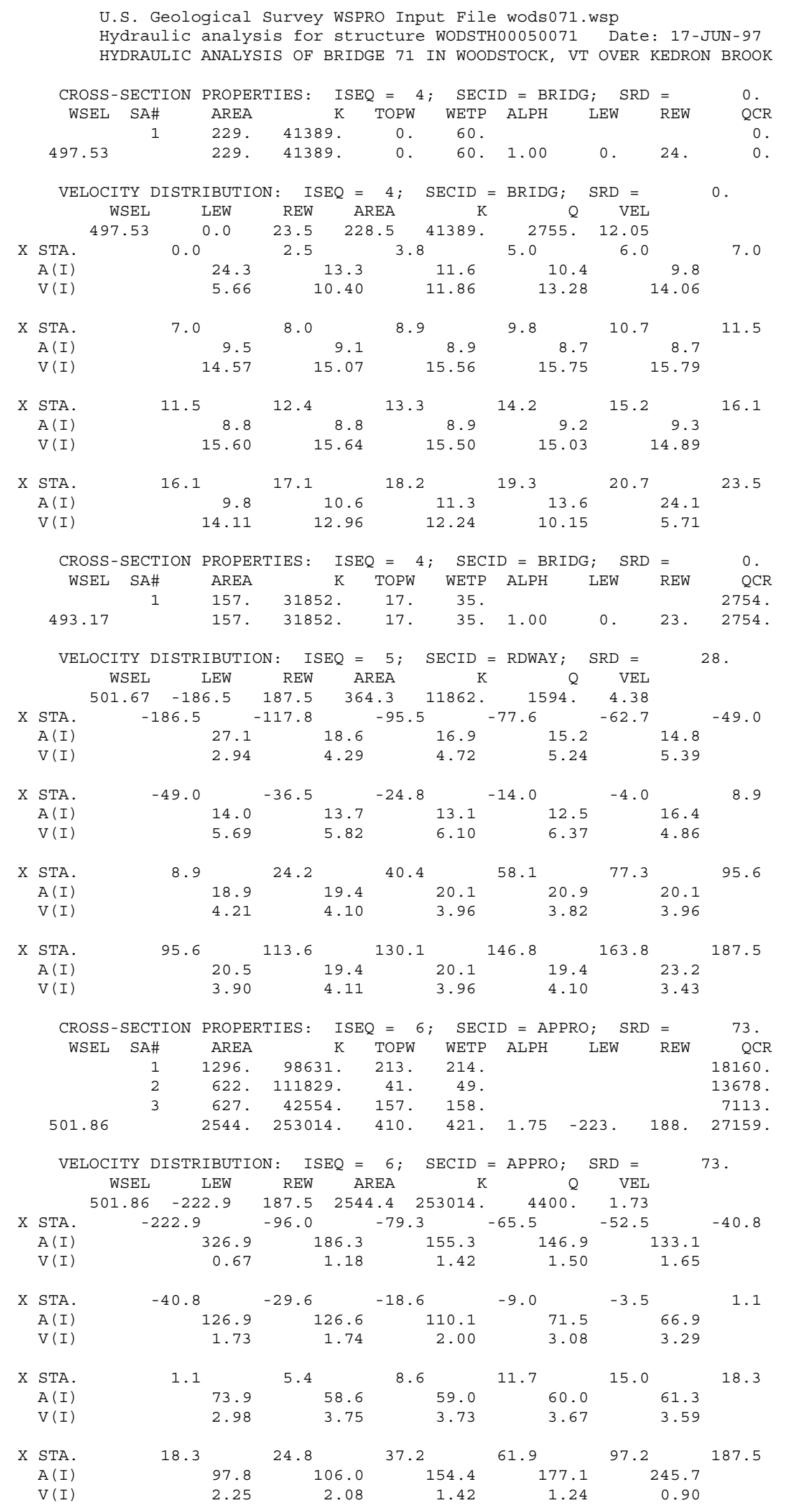


WSPRO OUTPUT FILE (continued)

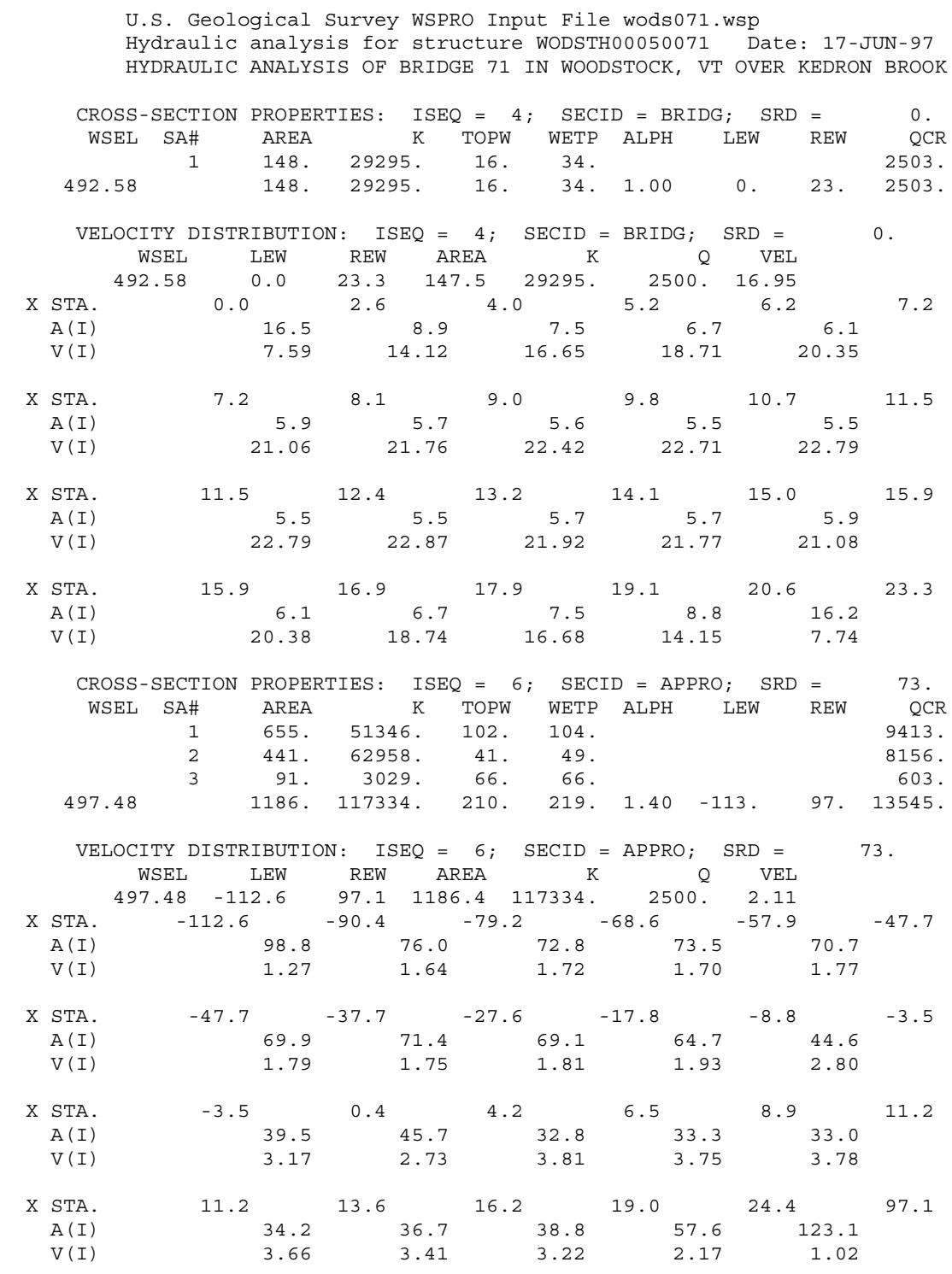


WSPRO OUTPUT FILE (continued)

U.S. Geological Survey WSPRO Input File wods071.wsp

Hydraulic analysis for structure WODSTH00050071 Date: 17-JUN-97

HYDRAULIC ANALYSIS OF BRIDGE 71 IN WOODSTOCK, VT OVER KEDRON BROOK

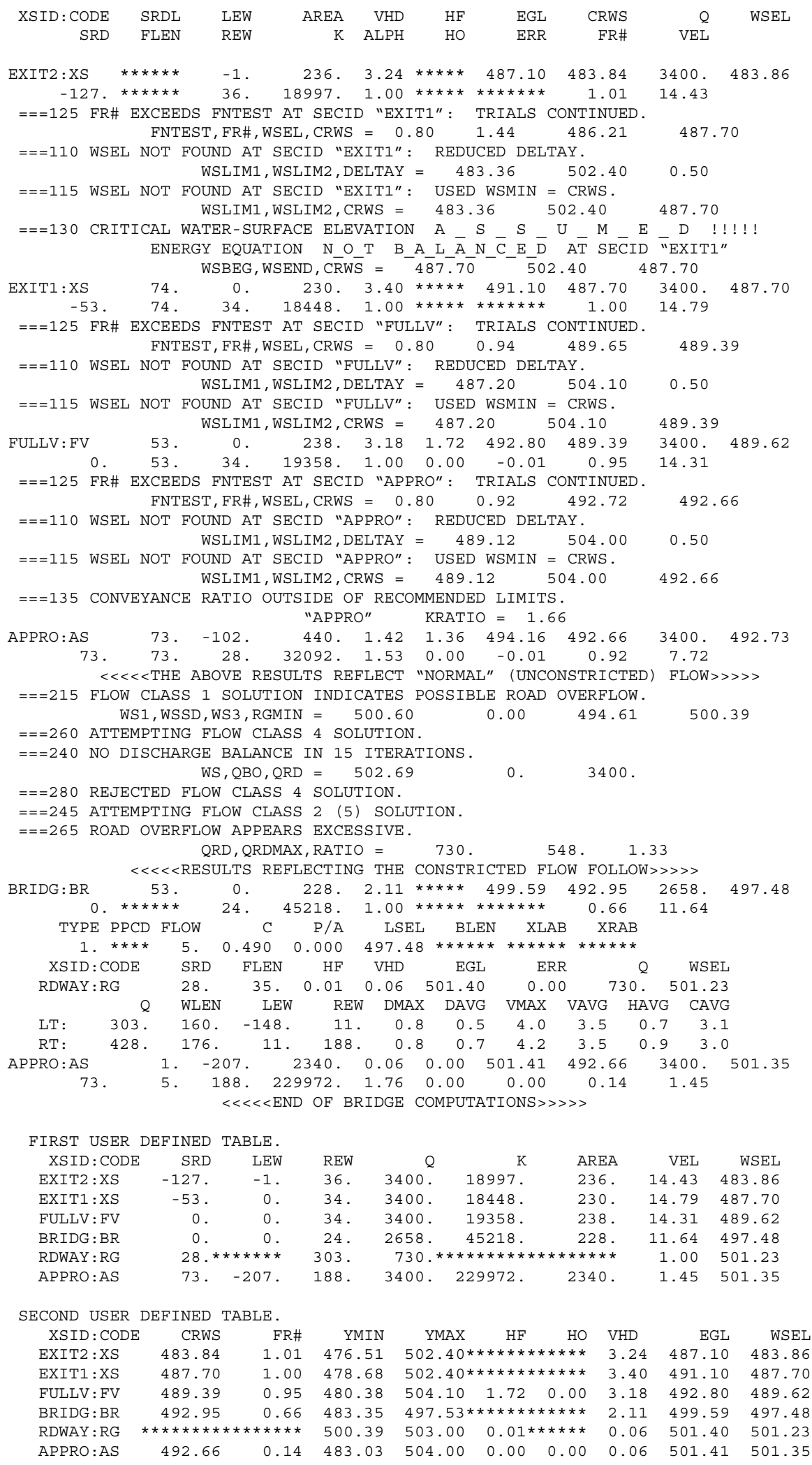


WSPRO OUTPUT FILE (continued)

U.S. Geological Survey WSPRO Input File wods071.wsp

Hydraulic analysis for structure WODSTH00050071 Date: 17-JUN-97

HYDRAULIC ANALYSIS OF BRIDGE 71 IN WOODSTOCK, VT OVER KEDRON BROOK

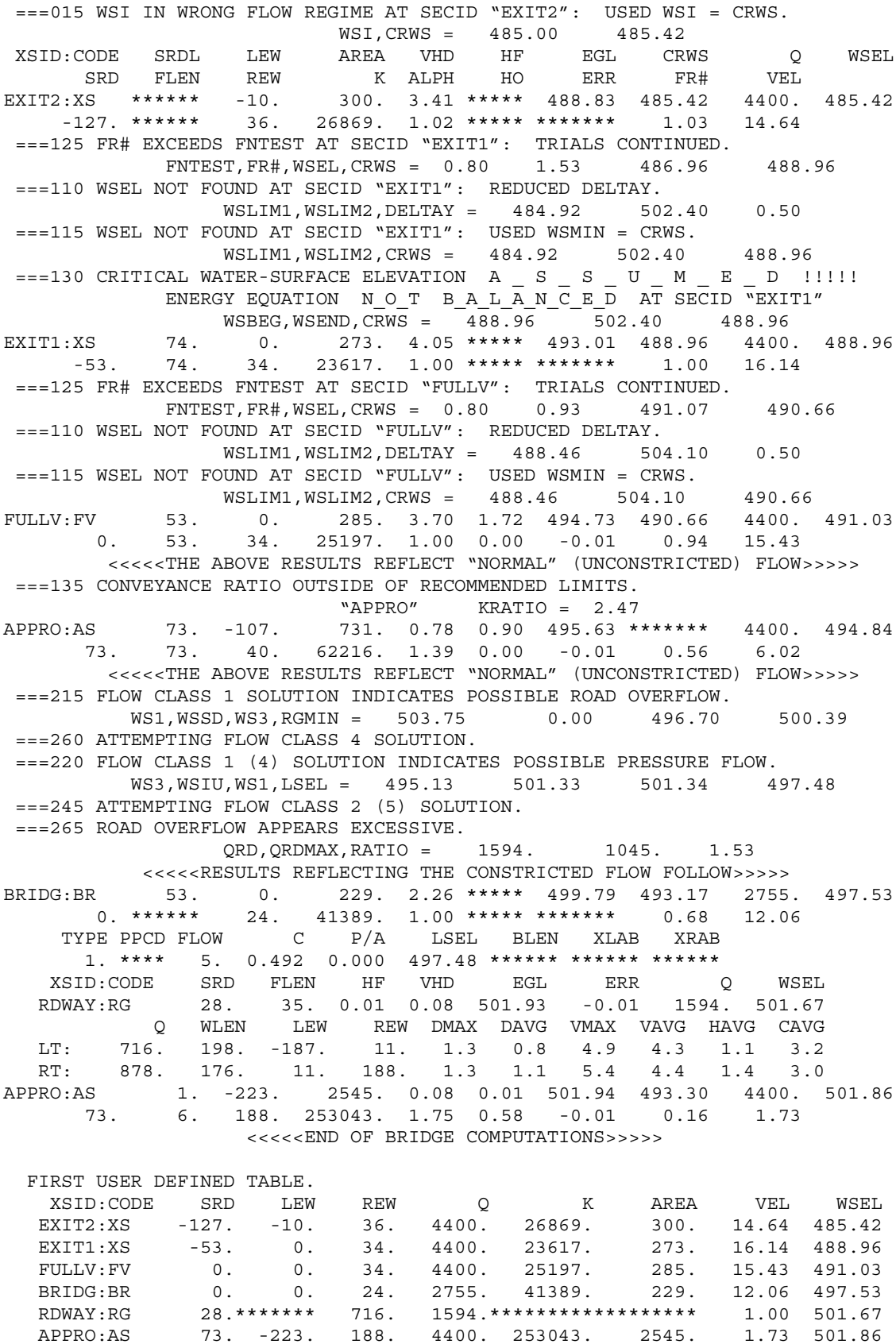

SECOND USER DEFINED TABLE.

$\begin{array}{lcrrrrrrrr}\text { XSID : CODE } & \text { CRWS } & \text { FR\# } & \text { YMIN } & \text { YMAX } & \text { HF } & \text { HO } & \text { VHD } & \text { EGL } & \text { WSEL } \\ \text { EXIT2 }: \text { XS } & 485.42 & 1.03 & 476.51 & 502.40 * * * * * * * * * * & 3.41 & 488.83 & 485.42 \\ \text { EXIT1 :XS } & 488.96 & 1.00 & 478.68 & 502.40 * * * * * * * * * * * & 4.05 & 493.01 & 488.96 \\ \text { FULLV : FV } & 490.66 & 0.94 & 480.38 & 504.10 & 1.72 & 0.00 & 3.70 & 494.73 & 491.03 \\ \text { BRIDG : BR } & 493.17 & 0.68 & 483.35 & 497.53 * * * * * * * * * * * & 2.26 & 499.79 & 497.53 \\ \text { RDWAY : RG } & * * * * * * * * * * * * * * * & 500.39 & 503.00 & 0.01 * * * * * * & 0.08 & 501.93 & 501.67 \\ \text { APPRO : AS } & 493.30 & 0.16 & 483.03 & 504.00 & 0.01 & 0.58 & 0.08 & 501.94 & 501.86\end{array}$


WSPRO OUTPUT FILE (continued)

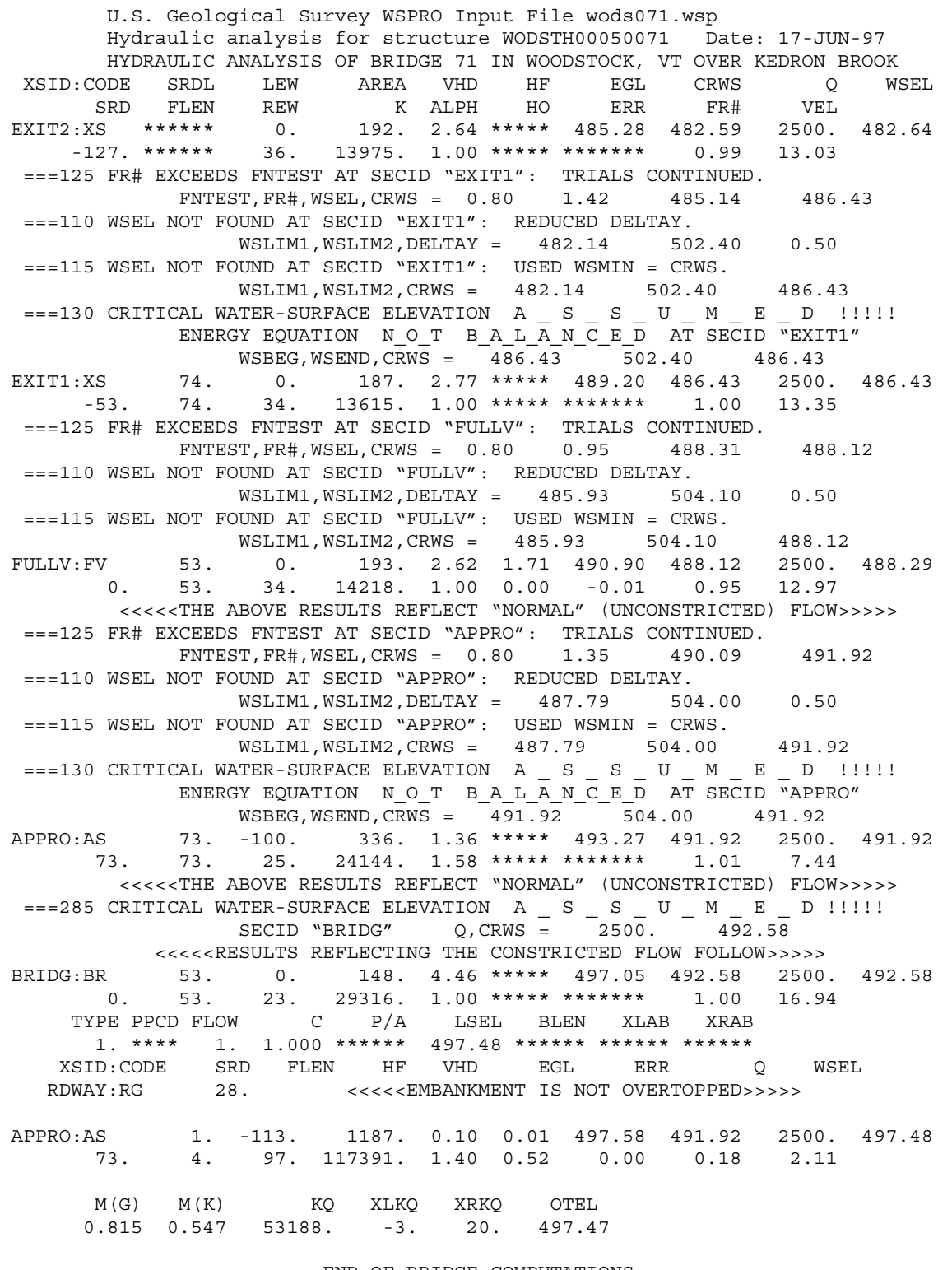

$<<<<$ END OF BRIDGE COMPUTATIONS $>>>>>$

\begin{tabular}{|c|c|c|c|c|c|c|c|c|}
\hline XSID : CODE & SRD & LEW & REW & $Q$ & $\mathrm{~K}$ & AREA & VEL & WSEL \\
\hline EXIT2:XS & -127. & 0 . & 36. & 2500 . & 13975. & 192. & 13.03 & 482.64 \\
\hline EXIT1:XS & -53. & 0 . & 34. & 2500 . & 13615. & 187. & 13.35 & 486.43 \\
\hline FULLV : FV & 0 . & 0 . & 34. & 2500 . & 14218. & 193. & 12.97 & 488.29 \\
\hline BRIDG : BR & 0 . & 0 . & 23. & 2500 . & 29316 . & 148. & 16.94 & 492.58 \\
\hline RDWAY : RG & \multicolumn{3}{|c|}{$28 . * \star \star * \star * \star * \star * \star \star \star * \star *$} & \multicolumn{3}{|c|}{ 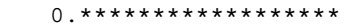 } & \multicolumn{2}{|c|}{$1.00 * \star \star * \star * * *$} \\
\hline APPRO: AS & 73. & -113. & 97. & 2500 . & 117391. & 1187. & 2.11 & 497.48 \\
\hline XSID : CODE & XLKQ & XRKQ & & & & & & \\
\hline APPRO: AS & -3 . & 20. & 5318 & & & & & \\
\hline
\end{tabular}

SECOND USER DEFINED TABLE.

$\begin{array}{lcrrrrrrrr}\text { XSID : CODE } & \text { CRWS } & \text { FR\# } & \text { YMIN } & \text { YMAX } & \text { HF } & \text { HO } & \text { VHD } & \text { EGL } & \text { WSEL } \\ \text { EXIT2:XS } & 482.59 & 0.99 & 476.51 & 502.40 * * * * * * * * * * & 2.64 & 485.28 & 482.64 \\ \text { EXIT1 :XS } & 486.43 & 1.00 & 478.68 & 502.40 * * * * * * * * * * * & 2.77 & 489.20 & 486.43 \\ \text { FULLV : FV } & 488.12 & 0.95 & 480.38 & 504.10 & 1.71 & 0.00 & 2.62 & 490.90 & 488.29 \\ \text { BRIDG : BR } & 492.58 & 1.00 & 483.35 & 497.53 * * * * * * * * * * * & 4.46 & 497.05 & 492.58 \\ \text { RDWAY : RG } & * * * * * * * * * * * * * * & 500.39 & 503.00 * * * * * * * * * * * * * * * * * * * * * * * * * * * * * \\ \text { APPRO: AS } & 491.92 & 0.18 & 483.03 & 504.00 & 0.01 & 0.52 & 0.10 & 497.58 & 497.48\end{array}$




\section{APPENDIX C:}

\section{BED-MATERIAL PARTICLE-SIZE DISTRIBUTION}




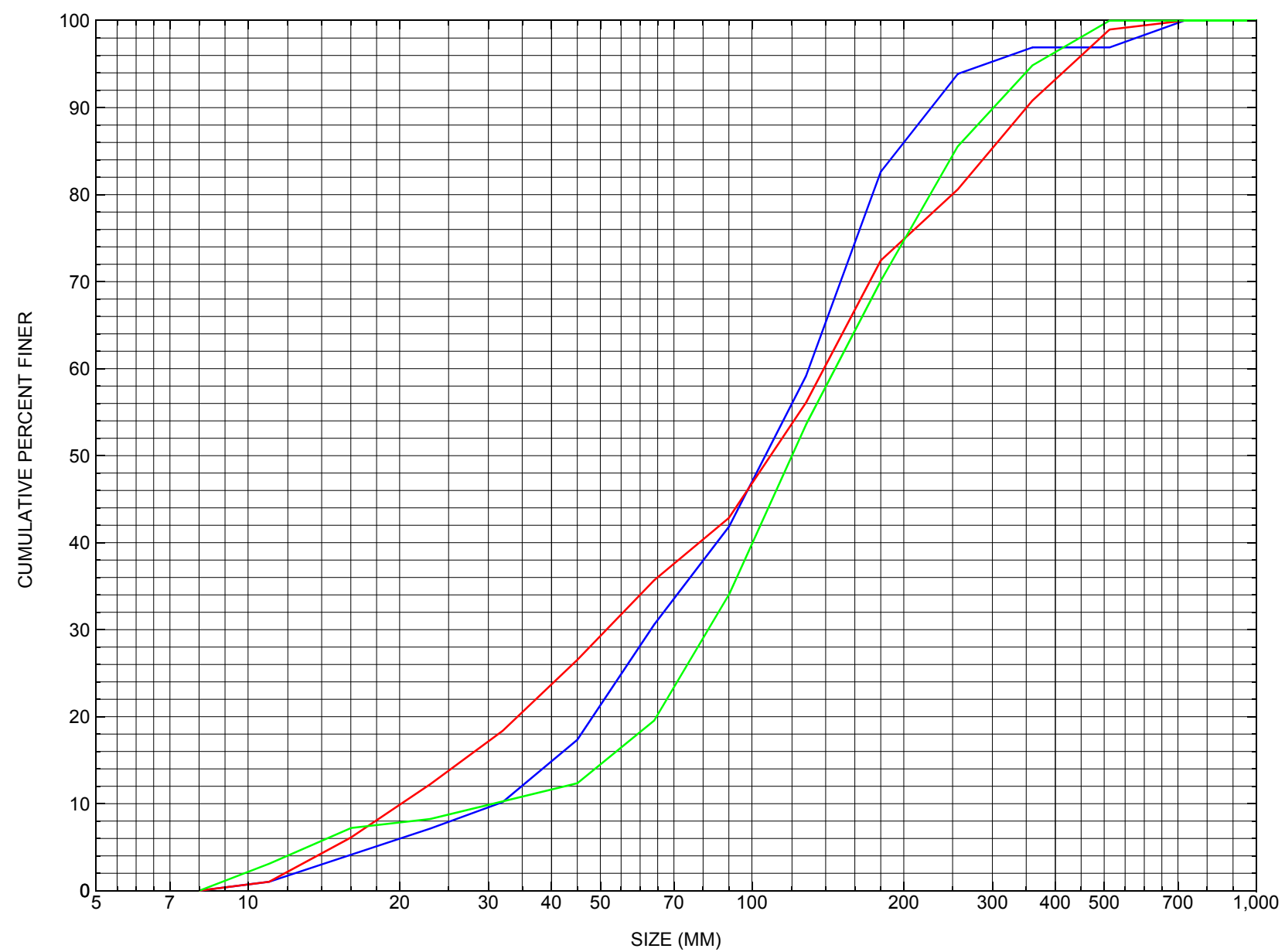

Appendix C. Bed material particle-size distribution for three pebble count transects in the channel approach of structure WODSTH00050071, in Woodstock, Vermont. 


\section{APPENDIX D: \\ HISTORICAL DATA FORM}




\section{Structure Number WODSTH00050071}

\section{General Location Descriptive}

Data collected by (First Initial, Full last name) $\mathbf{E}$. BOEHMLER

Date $(M M / D D / Y Y) \_\mathbf{0 8} / \underline{\mathbf{0 3}} / \underline{\mathbf{9 4}}$

Highway District Number (I - 2; nn) $\mathbf{0 4}$

Town (FIPS place code; I - 4; nnnnn) $\mathbf{8 5 9 0 0}$

Waterway (I - 6) KEDRON BROOK

Route Number TH005

Topographic Map Woodstock.North

Latitude (I - 16; nnnn.n) $\mathbf{4 3 3 7 6}$
County (FIPS county code; I - 3; nnn)

Mile marker (I - 11; nnn.nnn) $\mathbf{0 0 0 0 0 0}$

Road Name (I - 7): -

Vicinity (l - 9) 0.1 MI TO JCT W CL1 TH3

Hydrologic Unit Code: $\mathbf{0 1 0 8 0 1 0 6}$

Longitude (i - 17; nnnnn.n) $\mathbf{7 2 3 1 1}$

\section{Select Federal Inventory Codes}

FHWA Structure Number $(I$ - 8) $\mathbf{1 0 1 4 2 4 0 0 7 1 1 4 2 4}$

Maintenance responsibility $(I-21 ; n n) \quad \mathbf{0 3}$

Year built (I - 27; YYYY) 1950

Average daily traffic, ADT (I - 29; nnnnnn) 001200

Year of ADT (I - 30; YY) $\mathbf{9 4}$

Opening skew to Roadway $(I-34 ; n n) \quad 45$

Operational status $(I-41 ; X)$ A

Structure type (I - 43; nnn) 104

Approach span structure type (I - 44; nnn) $\mathbf{0 0 0}$

Number of spans (I - 45; nnn) $\mathbf{0 0 1}$

Number of approach spans (I - 46; nnnn) 0000

Comments:

Structural inspection report of 6/26/92 indicated undermining was present on the upstream end of the left wingwall. Channel scour was indicated as heavy at the bridge outlet. No embankment erosion or debris problems were noted. The channel makes a sharp turn into the bridge crossing. Stone fill is noted as good at the inlet but needed at outlet. No significant point bars were noted.
Maximum span length (I - 48; nnnn) $\underline{\mathbf{0 0 2 5}}$

Structure length (I - 49; nnnnnn) $\underline{\mathbf{0 0 0 0 3 0}}$

Deck Width (I - 52; nn.n) 379

Channel \& Protection $(I-61 ; n) \underline{5}$

Waterway adequacy $(I-71 ; n) \underline{6}$

Underwater Inspection Frequency $(I-92 B ; X Y Y) \_$N

Year Reconstructed (I - 106) $\mathbf{0 0 0 0}$

Clear span (nnn.n ft) _

Vertical clearance from streambed (nnn.n ft) $\underline{\mathbf{1 2 . 3}}$

Waterway of full opening $\left(n n n . n \mathrm{ft}^{2}\right)$ 


\section{Bridge Hydrologic Data}

Is there hydrologic data available? $\underline{\mathbf{N}}$ if No, type ctrl- $h \quad$ VTAOT Drainage area $\left(m i^{2}\right): \underline{\mathbf{1 6 . 0 8}}$

Terrain character:

Stream character \& type: -

Streambed material:

Discharge Data (cfs):

$$
\mathrm{Q}_{2.33} \frac{-}{\mathbf{3 0 0 0}}
$$

$Q_{10} \frac{\mathbf{1 6 5 0}}{\mathbf{3 4 0 0}}$

$\mathrm{Q}_{25} \lcm{\mathbf{2 3 0 0}}$

$\mathrm{Q}_{500}$

Record flood date (MM/DD/YY): - $/$ - $/$ Water surface elevation $(f t):-$

Estimated Discharge (cfs): Velocity at $\mathrm{Q}$ $(\mathrm{ft} / \mathrm{s}):$

Ice conditions (Heavy, Moderate, Light) : Debris (Heavy, Moderate, Light): Light

The stage increases to maximum highwater elevation (Rapidly, Not rapidly):

The stream response is (Flashy, Not flashy):

Describe any significant site conditions upstream or downstream that may influence the stream's stage: -

Watershed storage area (in percent):

The watershed storage area is: - _ (1-mainly at the headwaters; 2- uniformly distributed; 3-immediatly upstream oi the site)

Water Surface Elevation Estimates for Existing Structure:

\begin{tabular}{|l|l|l|l|l|l|}
\hline Peak discharge frequency & $Q_{2.33}$ & $Q_{10}$ & $Q_{25}$ & $Q_{50}$ & $Q_{100}$ \\
Water surface elevation (ft) & - & $\mathbf{6 9 0 . 2}$ & - & - & $\mathbf{6 9 5 . 1}$ \\
Velocity (ft/sec) & - & - & - & - & - \\
\hline
\end{tabular}

Long term stream bed changes: -

Is the roadway overtopped below the $\mathrm{Q}_{100}$ ? (Yes, No, Unknown): $\mathbf{U} \quad$ Frequency: Relief Elevation $(f t)$ : Discharge over roadway at $\mathrm{Q}_{100}\left(\mathrm{ft}^{3} / \mathrm{sec}\right)$ :

Are there other structures nearby? (Yes, No, Unknown): $\mathbf{U}$ Upstream distance (miles): Town: If No or Unknown, type ctrl-n os Highway No. : Structure No. : Year Built:

Clear span (ft): Clear Height (ft): Full Waterway $\left(f t^{2}\right)$ : 
Downstream distance (miles): Town: Year Built:

Highway No. : Structure No. : Structure Type:

Clear span (ft): Clear Height $(f t)$ : Full Waterway $\left(f t^{2}\right)$ :

Comments:

\section{USGS Watershed Data}

Watershed Hydrographic Data

Drainage area $(D A) \underline{16.05} \mathrm{mi}^{2}$ Lake/pond/swamp area 0.01 $\mathrm{mi}^{2}$

Watershed storage (ST) 0.1

Bridge site elevation 690 $\mathrm{ft}$ $\%$

Main channel length 10.67 $\mathrm{mi}$ $10 \%$ channel length elevation 700 $\mathrm{ft} \quad 85 \%$ channel length elevation $\mathrm{ft}$

Main channel slope $(S)$

(S) 109.96 $\mathrm{ft} / \mathrm{mi}$

Watershed Precipitation Data

Average site precipitation in Average headwater precipitation in

Maximum 2yr-24hr precipitation event $(124,2)$ in

Average seasonal snowfall (Sn) $\mathrm{ft}$ 


\section{Bridge Plan Data}

Are plans available? $\underline{\mathbf{Y}}$ If no, type ctrl-n pl Date issued for construction (MM/YYYY): $\underline{07}$ / 1981

Project Number TF 1950 \& TF 2121

Low superstructure elevation: USLAB 97.24** DSLAB 97.17 USRAB 97.22 DSRAB 97.09

Benchmark location description:

BM \#1, spike in the root or trunk of a 36 inch elm tree located about 150 feet left bankward from the left abutment along the roadway centerline, then about 15 feet perpendicular to the centerline in an upstream direction to the tree at the base of the roadway embankment, elevation 100.77.

Reference Point (MSL, Arbitrary, Other): Arbitrary $\quad$ Datum (NAD27, NAD83, Other): Arbitrary Foundation Type: 1 (1-Spreadfooting; 2-Pile; 3- Gravity; 4-Unknown)

If 1: Footing Thickness $\mathbf{3 . 5} \quad$ Footing bottom elevation: $\mathbf{7 9 . 0}$

If 2: Pile Type: __ (1-Wood; 2-Steel or metal; 3-Concrete) Approximate pile driven length: -

If 3: Footing bottom elevation: -

Is boring information available? $\underline{\mathbf{Y}}$ If no, type ctrl-n bi Number of borings taken: $\underline{\mathbf{3}}$

Foundation Material Type: 1 (1-regolith, 2-bedrock, 3-unknown)

Briefly describe material at foundation bottom elevation or around piles:

Borings all show sand at shallow depths and then rocks, a boulder, or ledge at depth. Boring information was taken from the plans of 1950. The bottom of the borings taken on the right abutment side were higher than the proposed bottom of footing. The two borings on the right side show rocks and boulder or bedrock material at the bottom; refusal depth greater than an elevation of 80.0. The one boring taken on the left abutment side shows bedrock at the footing elevation.

Comments:

*The channel bed under the bridge was covered in 1981 with a 1 foot thick concrete slab resting on top of both footings with a top elevation of 678.0. Original abutment footings were 3.5 feet thick. Renovation work in 1981 poured additional 2 and 2.5 foot thick footings as extensions to the old footings. The inlet cutoff wall on the bottom channel slab extends down 4 feet. The hydraulic information entered above was from the plans. Other elevations from the plans are: downstream left wingwall top 694.95 and right wingwall top 694.89.

** Low superstructure elevations found on the T-1 1950 plans.

Benchmark for 1981 plans shows a spike in a 15 inch butternut, elevation 691.14, located 130 feet west on TH 5 (Pleasant street) travelling from the left bank, then 20 feet off the left hand side of the road. BM\#2, bolt on hydrant cap, elevation 695.83, located 120 feet east on TH 5 travelling from the right bank, then just on the curb, right 


\section{Cross-sectional Data}

Is cross-sectional data available? $\underline{\mathbf{Y}}$ If no, type ctrl-n xs

Source (FEMA, VTAOT, Other)? VTAOT

Comments: Upstream bridge face cross section from left to right abutment. The footings extend into the channel 1.5 feet with a top elevation at 82.5 and a base at 79.0. A 1 foot thick concrete slab rest on top of both footings forming the bed elevation below.

\begin{tabular}{|l|l|l|l|l|l|l|l|l|l|l|l|}
\hline Station & $\mathbf{2 . 0}$ & $\mathbf{9 . 5}$ & $\mathbf{2 2 . 5}$ & & & & & & & & \\
\hline Feature & LCL & & LCR & & & & & & & & \\
\hline $\begin{array}{l}\text { Low chord } \\
\text { elevation }\end{array}$ & $\mathbf{9 7 . 2}$ & & $\mathbf{9 7 . 4}$ & & & & & & & & \\
\hline $\begin{array}{l}\text { Bed } \\
\text { elevation }\end{array}$ & $\mathbf{8 3 . 5}$ & $\mathbf{8 3 . 0 8}$ & $\mathbf{8 3 . 5}$ & & & & & & & & \\
\hline $\begin{array}{l}\text { Low chord- } \\
\text { bed }\end{array}$ & $\mathbf{1 3 . 7}$ & & $\mathbf{1 3 . 9}$ & & & & & & & & \\
\hline Station & & & & & & & & & & & \\
\hline Feature & & & & & & & & & & & \\
\hline $\begin{array}{l}\text { Low chord } \\
\text { elevation }\end{array}$ & & & & & & & & & & & \\
\hline $\begin{array}{l}\text { Bed } \\
\text { elevation }\end{array}$ & & & & & & & & & & & \\
\hline $\begin{array}{l}\text { Low chord- } \\
\text { bed }\end{array}$ & & & & & & & & & & & \\
\hline
\end{tabular}

Source (FEMA, VTAOT, Other)? VTAOT

Comments: Downstream bridge face cross section left to right abutment.The footings extend into the channel 1.5 feet with a top elevation at 82.5 and a base at 79.0.

\begin{tabular}{|l|l|l|l|l|l|l|l|l|l|l|l|}
\hline Station & $\mathbf{2 . 0}$ & $\mathbf{9 . 5}$ & $\mathbf{2 2 . 5}$ & & & & & & & & \\
\hline Feature & LCL & & LCR & & & & & & & & \\
\hline $\begin{array}{l}\text { Low chord } \\
\text { elevation }\end{array}$ & $\mathbf{9 7 . 3}$ & & $\mathbf{9 7 . 2}$ & & & & & & & & \\
\hline $\begin{array}{l}\text { Bed } \\
\text { elevation }\end{array}$ & $\mathbf{8 3 . 5}$ & $\mathbf{8 3 . 0 8}$ & $\mathbf{8 3 . 5}$ & & & & & & & & \\
\hline $\begin{array}{l}\text { Low chord- } \\
\text { bed }\end{array}$ & $\mathbf{1 3 . 8}$ & & $\mathbf{1 3 . 7}$ & & & & & & & & \\
\hline Station & & & & & & & & & & & \\
\hline Feature & & & & & & & & & & & \\
\hline $\begin{array}{l}\text { Low chord } \\
\text { elevation }\end{array}$ & & & & & & & & & & & \\
\hline $\begin{array}{l}\text { Bed } \\
\text { elevation }\end{array}$ & & & & & & & & & & & \\
\hline $\begin{array}{l}\text { Low chord- } \\
\text { bed }\end{array}$ & & & & & & & & & & & \\
\hline
\end{tabular}




\section{APPENDIX E: \\ LEVEL I DATA FORM}


U. S. Geological Survey

Bridge Field Data Collection and Processing Form

Qa/Qc Check by: JDA

Date: $2 / 14 / 95$

\section{Structure Number WODSTH00050071}

Computerized by: MAI Date: $\underline{\mathbf{3} / \mathbf{1 6} / \mathbf{9 5}}$

Reviewd by: SAO Date: $\underline{\mathbf{8} / \mathbf{2 2} / \mathbf{9 7}}$

\section{A. General Location Descriptive}

1. Data collected by (First Initial, Full last name) $\mathbf{J}$. AYOTTE

Date $(M M / D D / Y Y) \quad 09 / 14 / 1994$

2. Highway District Number 04

Mile marker $\mathbf{0}$

County WINDSOR (027)

Town WOODSTOCK (85900)

Waterway (I - 6) KEDRON BROOK

Road Name PLEASANT STREET

Route Number TH005

Hydrologic Unit Code: $\mathbf{0 1 0 8 0 1 0 6}$

3. Descriptive comments:

Bridge is a box culvert; downstream end of concrete channel spills about $4 \mathrm{ft}$. to the stream bed below. All wingwalls are concrete except the USRWW which is drywall. Downstream is essentially channelized by concrete walls.

0.1 miles to the junction of TH 5 and TH 3.

\section{B. Bridge Deck Observations}
4. Surface cover... LBUS 6
RBUS 5
LBDS 2
RBDS 2
Overall 2

(2b us, ds,lb,rb: 1- Urban; 2- Suburban; 3- Row crops; 4- Pasture; 5- Shrub- and brushland; 6- Forest; 7- Wetland)
5. Ambient water surface...US $\underline{2}$
UB 1
DS $\underline{2}$
(1- pool; 2- riffle)

6. Bridge structure type 6 (1- single span; 2- multiple span; 3- single arch; 4- multiple arch; 5-cylindrical culvert; 6- box culvert; or 7- other)
7. Bridge length $\underline{\mathbf{3 0}}$
(feet)
Span length 25
(feet)
Bridge width $\underline{\mathbf{3 7 . 9}}$ (feet)

\section{Road approach to bridge:}
8. LB 1
RB 2
( 0 even, 1- lower, 2- higher)
9. LB
RB 1
(1- Paved, 2- Not paved)

10. Embankment slope (run / rise in feet / foot)

$$
\text { US left }
$$

2.3:1

US right $\quad 2.4: 1$

\begin{tabular}{|c|c|c|c|c|}
\hline & \multicolumn{2}{|c|}{ Protection } & \multirow{2}{*}{ 13.Erosion } & \multirow{2}{*}{ 14.Severity } \\
\hline & 11.Type & 12. Cond. & & \\
\hline LBUS & $\mathbf{0}$ & - & $\mathbf{0}$ & $\mathbf{0}$ \\
\hline RBUS & $\mathbf{0}$ & - & $\mathbf{0}$ & $\mathbf{0}$ \\
\hline RBDS & $\mathbf{0}$ & - & $\mathbf{0}$ & $\mathbf{0}$ \\
\hline LBDS & $\mathbf{0}$ & - & $\mathbf{0}$ & $\mathbf{0}$ \\
\hline
\end{tabular}

Bank protection types: 0- none; 1- < 12 inches;

$$
\text { 2- < } 36 \text { inches; 3- < } 48 \text { inches; }
$$

4- < 60 inches; 5- wall / artificial levee

Bank protection conditions: 1- good; 2- slumped;

3- eroded; 4- failed

Erosion: 0 - none; 1- channel erosion; 2

road wash; 3- both; 4- other

Erosion Severity: 0 - none; 1- slight; 2- moderate; 3- severe

\section{Channel approach to bridge (BF):}

15. Angle of approach: $\mathbf{4 2}$

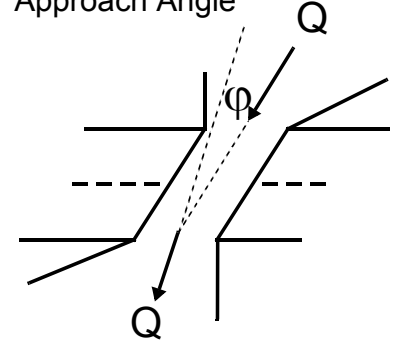

17. Channel impact zone 1 :

Where? LB (LB, RB)

Range? 35 feet US

Channel impact zone 2:

Where? (LB, RB)

Range? feet (US, UB, DS) to feet

16. Bridge skew: $\mathbf{4 5}$ Bridge Skew Angle

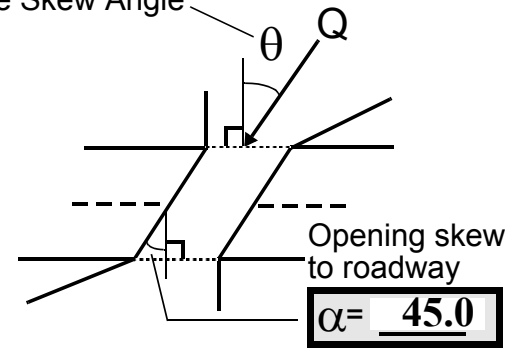

\section{Exist? $\underline{\mathbf{Y}}(\mathrm{Y}$ or $N)$}

Severity 3

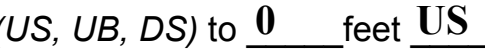

Exist? $\underline{\mathbf{N}}(\mathrm{Y}$ or $N)$

Severity

Impact Severity: 0- none to very slight; 1- Slight; 2- Moderate; 3- Severe 
18. Bridge Type: 4

1a- Vertical abutments with wingwalls

$1 \mathrm{~b}$ - Vertical abutments without wingwalls

2- Vertical abutments and wingwalls, sloping embankment Wingwalls parallel to abut. face

3- Spill through abutments

4- Sloping embankment, vertical wingwalls and abutments

Wingwall angle less than $90^{\circ}$.

19. Bridge Deck Comments (surface cover variations, measured bridge and span lengths, bridge type variations, approach overflow width, etc.)

7. Measured length: 28, span: 24.5, width: 38 feet.

Box culvert with type 4 wingwalls. Upstream invert of the culvert is $20 \mathrm{ft}$ below the top of rail post which rises $3.8 \mathrm{ft}$ above surveyed reference mark with point number 156. Downstream invert was surveyed with the total station. Two drains ( 4 in and 8 in) enter the downstream end of the left abutment. Inside abutment length is 70 ft. Five drains ( $3 \mathrm{in}$ ) are evenly spaced along the abutments, $3 \mathrm{ft}$. above the base of the walls.

\section{Upstream Channel Assessment}

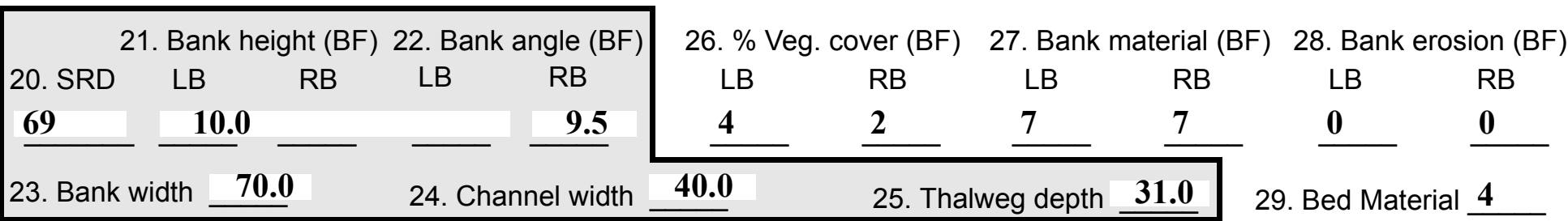

30 .Bank protection type:

LB $\underline{2}$

RB 5

31. Bank protection condition: LB 1

RB 1

SRD - Section ref. dist. to US face \% Vegetation (Veg) cover: 1- 0 to 25\%; 2- 26 to 50\%; 3- 51 to $75 \%$; 4- 76 to $100 \%$

Bed and bank Material: 0- organics; 1- silt / clay, < 1/16mm; 2- sand, 1/16 - 2mm; 3- gravel, 2 - 64mm;

4- cobble, 64 - 256mm; 5- boulder, > 256mm; 6- bedrock; 7- manmade

Bank Erosion: 0- not evident; 1- light fluvial; 2- moderate fluvial; 3- heavy fluvial / mass wasting

Bank protection types: 0- absent; 1- < 12 inches; 2- < 36 inches; 3- < 48 inches; 4- < 60 inches; 5- wall / artificial levee

Bank protection conditions: 1-good; 2- slumped; 3- eroded; 4- failed

32. Comments (bank material variation, minor inflows, protection extent, etc.):

30. Right bank protection is a $6 \mathrm{ft}$ tall drywall extending several hundred feet upstream to the next bridge.

The stone fill on the left bank is lower than the drywall. 
36. Point bar extent: 0 feet US

(US, UB) to 35 feet $\underline{\mathbf{U S}}$

(US, UB, DS) positioned 90 \%LB to 100 \%RB

37. Material: 3

38. Point or side bar comments (Circle Point or Side; Note additional bars, material variation, status, etc.):

Some of the point bar consists of dumped stone; it is the cause (in part) of the bar development; it creates a flow shadow and sediment accumulates here.

39. Is a cut-bank present? $\mathbf{N}$ ( $Y$ or if $N$ type ctrl-n $c b)$

40. Where? (LB or $R B)$

41. Mid-bank distance: -

42. Cut bank extent: feet (US, UB) to feet (US, UB, DS)

43. Bank damage: (1- eroded and/or creep; 2- slip failure; 3- block failure)

44. Cut bank comments (eg. additional cut banks, protection condition, etc.):

NO CUT BANKS

\section{Is channel scour present? $\mathbf{Y}$ (Y or if $N$ type ctrl-n cs)}

47. Scour dimensions: Length $\mathbf{5}$ Width $\underline{3}$ Depth : 2

46. Mid-scour distance: 20

48. Scour comments (eg. additional scour areas, local scouring process, etc.):

Scour is due to impact with the upstream left bank and upstream left wingwall area.

49. Are there major confluences? $\mathbf{N}$

51. Confluence 1: Distance Confluence 2: Distance 52. Enters on Enters on 54. Confluence comments (eg. confluence name):

NO MAJOR CONFLUENCES
50. How many? -

53. Type(1- perennial; 2- ephemeral)

Type (1-perennial; 2-ephemeral)

\section{Under Bridge Channel Assessment}

55. Channel restraint (BF)? LB 2

\begin{tabular}{|ccccc}
\hline \multicolumn{2}{|c}{ 56. Height (BF) } & \multicolumn{3}{c}{57 Angle (BF) } \\
LB & RB & LB & RB \\
$\mathbf{1 7 . 0}$ & & & $\mathbf{1 . 0}$ & \\
\hline
\end{tabular}

58. Bank width (BF) (1- natural bank; 2- abutment; 3- artificial levee)

Bed and bank Material: 0- organics; 1- silt / clay, < 1/16mm; 2- sand, 1/16 - 2mm; 3- gravel, 2 - 64mm; 4- cobble, 64 - 256mm; 5- boulder, > 256mm; 6- bedrock; 7- manmade

61. Material (BF) 62. Erosion (BF)

LB RB LB RB

$\underline{2} \quad \underline{7} \quad \underline{7}$

59. Channel width -

60. Thalweg depth $\mathbf{9 0 . 0}$

63. Bed Material $\mathbf{0}$

Bank Erosion: 0- not evident; 1- light fluvial; 2- moderate fluvial; 3- heavy fluvial / mass wasting

64. Comments (bank material variation, minor inflows, protection extent, etc.):

7

Inside dimensions of the culvert are $70 \mathrm{ft}$. long by $17.2 \mathrm{ft}$. wide. 
65. Debris and Ice Is there debris accumulation? (Yor $N)$ 66. Where? $\mathbf{N}$ (1- Upstream; 2- At bridge; 3- Both)

67. Debris Potential ( 1- Low; 2- Moderate; 3- High) 68. Capture Efficiency 1 (1-Low; 2- Moderate; 3- High) 69. Is there evidence of ice build-up? 1 ( $Y$ or $N)$ Ice Blockage Potential $\mathbf{N}$ (1- Low; 2- Moderate; 3- High)

70. Debris and Ice Comments:

1

67. No debris accumulation near the bridge, upstream is laterally stable, has few cut banks, and consists of cobble material.

68. High gradient stream and the span is about $80 \%$ of the upstream bank width.

Site visit on 12/14/94 revealed a significant elevation of the water surface (1-2 ft.) due to anchor ice and ice

\begin{tabular}{|c|c|c|c|c|c|c|c|c|}
\hline Abutments & $\begin{array}{l}\text { 71. Attack } \\
\angle(\mathrm{BF})\end{array}$ & $\begin{array}{l}\text { 72. Slope } \angle \\
\text { (Qmax) }\end{array}$ & $\begin{array}{l}\text { 73. Toe } \\
\text { loc. (BF) }\end{array}$ & $\begin{array}{l}\text { 74. Scour } \\
\text { Condition }\end{array}$ & $\begin{array}{c}\text { 75. Scour } \\
\text { depth }\end{array}$ & $\begin{array}{c}\text { 76. Exposure } \\
\text { depth }\end{array}$ & 77. Material & 78. Length \\
\hline LABUT & build & up & on & the & wate & r. & 30 & 90.0 \\
\hline RABUT & 90 & 2 & $\mathbf{0}$ & & & $\mathbf{0}$ & $\mathbf{0}$ & 16.6 \\
\hline
\end{tabular}

Pushed: $L B$ or RB

Toe Location (Loc.): 0- even, 1- set back, 2- protrudes

Scour cond.: 0- not evident; 1- evident (comment); 2- footing exposed; 3-undermined footing; 4- piling exposed; 5- settled; 6- failed

Materials: 1- Concrete; 2- Stone masonry or drywall; 3- steel or metal; 4- wood

79. Abutment comments (eg. undermined penetration, unusual scour processes, debris, etc.):

1

90

2

0

0

0

1

No scour on abutments; bridge is a box culvert with a concrete bottom. Scour processes are occurring at the USLWW and downstream due to a drop at the end of the box culvert.

80. Wingwalls:

Exist? Material? Scour Scour Exposure 81.

USLWW: Condition? depth? depth?

USRWW:

DSLWW:

DSRWW: 1

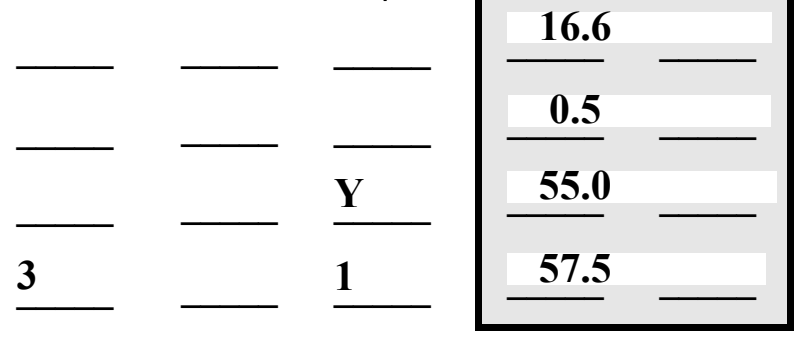

Wingwall materials: 1- Concrete; 2- Stone masonry or drywall; 3- steel or metal; 4- wood

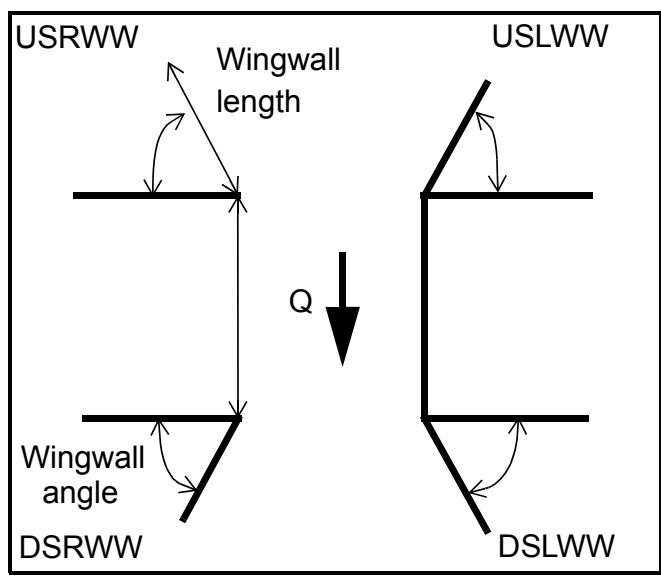

82. Bank / Bridge Protection:

\begin{tabular}{|l|l|l|l|l|l|l|l|l|}
\hline Location & USLWW & USRWW & LABUT & RABUT & LB & RB & DSLWW & DSRWW \\
\hline Type & $\mathbf{3 . 5}$ & $\mathbf{0}$ & $\mathbf{Y}$ & $\mathbf{0 . 5}$ & $\mathbf{1}$ & $\mathbf{3 . 5}$ & - & $\mathbf{2}$ \\
\hline Condition & $\mathbf{Y}$ & $\mathbf{0}$ & $\mathbf{1}$ & $\mathbf{2}$ & $\mathbf{2}$ & $\mathbf{0}$ & $\mathbf{2}$ & $\mathbf{0}$ \\
\hline Extent & $\mathbf{2}$ & $\mathbf{0}$ & $\mathbf{2}$ & $\mathbf{Y}$ & $\mathbf{2 . 5}$ & - & $\mathbf{1}$ & - \\
\hline
\end{tabular}

Bank / Bridge protection types: 0- absent; 1- < 12 inches; 2- < 36 inches; 3- < 48 inches; 4- < 60 inches; 
83. Wingwall and protection comments (eg. undermined penetration, unusual scour processes, etc.):

0

$-$

$-$

0

0

$-$

$-$

0

\section{Piers:}

84. Are there piers? _ _ (Y or if $N$ type ctrl-n pr)

\begin{tabular}{|l|l|l|l|l|l|l|l|}
\hline \multirow{2}{*}{$\begin{array}{l}85 . \\
\text { Pier no. }\end{array}$} & \multicolumn{3}{|c|}{ width (w) feet } & \multicolumn{5}{c|}{ elevation (e) feet } \\
\cline { 2 - 8 } & w1 & w2 & w3 & e@w1 & e@w2 & e@w3 \\
\hline Pier 1 & & & & $\mathbf{1 5 . 0}$ & $\mathbf{3 1 . 0}$ & $\mathbf{1 3 5 . 0}$ \\
\hline Pier 2 & & & & $\mathbf{3 4 . 0}$ & $\mathbf{1 3 5 . 0}$ & $\mathbf{3 8 . 0}$ \\
\hline Pier 3 & & & - & $\mathbf{1 5 . 0}$ & $\mathbf{3 7 . 5}$ & - \\
\hline Pier 4 & - & - & - & - & - & - \\
\hline
\end{tabular}

\begin{tabular}{|l|l|l|l|l|}
\hline Level 1 Pier Descr. & \multicolumn{1}{|c|}{1} & \multicolumn{1}{|c|}{2} & \multicolumn{1}{|c|}{3} & \multicolumn{1}{|c|}{4} \\
\hline 86. Location (BF) & - & with & m top & d pen- \\
\hline 87. Type & $\mathbf{0}$ & total & of & etrat \\
\hline 88. Material & - & expo & foot- & e up \\
\hline 89. Shape & - & sure & ing & to \\
\hline 90. Inclined? & $\mathbf{8 0 .}$ & dept & to & $\mathbf{2 . 3}$ \\
\hline 91. Attack $\angle$ (BF) & The & h of & strea & ft. \\
\hline 92. Pushed & USL & appr & mbe & into \\
\hline 93. Length (feet) & - & - & - & - \\
\hline 94. \# of piles & WW & oxi- & d). & the \\
\hline 95. Cross-members & is & mate & Ran & bank \\
\hline 96. Scour Condition & unde & ly & ge & unde \\
\hline 97. Scour depth & rmin & $\mathbf{3 . 5} \mathbf{f t}$ & pole & r the \\
\hline 98. Exposure depth & ed & (fro & coul & wing \\
\hline
\end{tabular}

LFP, LTB, LB, MCL, MCM, MCR, RB, RTB, RFP

1- Solid pier, 2-column, 3- bent

1-Wood; 2- concrete; 3- metal; 4- stone

1- Round; 2- Square; 3- Pointed

Y-yes; $N$ - no

$L B$ or $R B$

0- none; 1- laterals; 2- diagonals; 3- both

0- not evident; 1- evident (comment);

2- footing exposed; 3- piling exposed;

4- undermined footing; 5- settled; 6-failed 
99. Pier comments (eg. undermined penetration, protection and protection extent, unusual scour processes, etc.):

wall footing. This wingwall has a 2 in crack (vertical) probably due to settling associated with scour.

Banks upstream and downstream are protected but the wingwalls are not protected.

Downstream wingwalls are scoured with footings exposed. Footing exposure is variable due to variable elevation of finished footing tops.

$\mathbf{N}$

100.

\section{E. Downstream Channel Assessment}

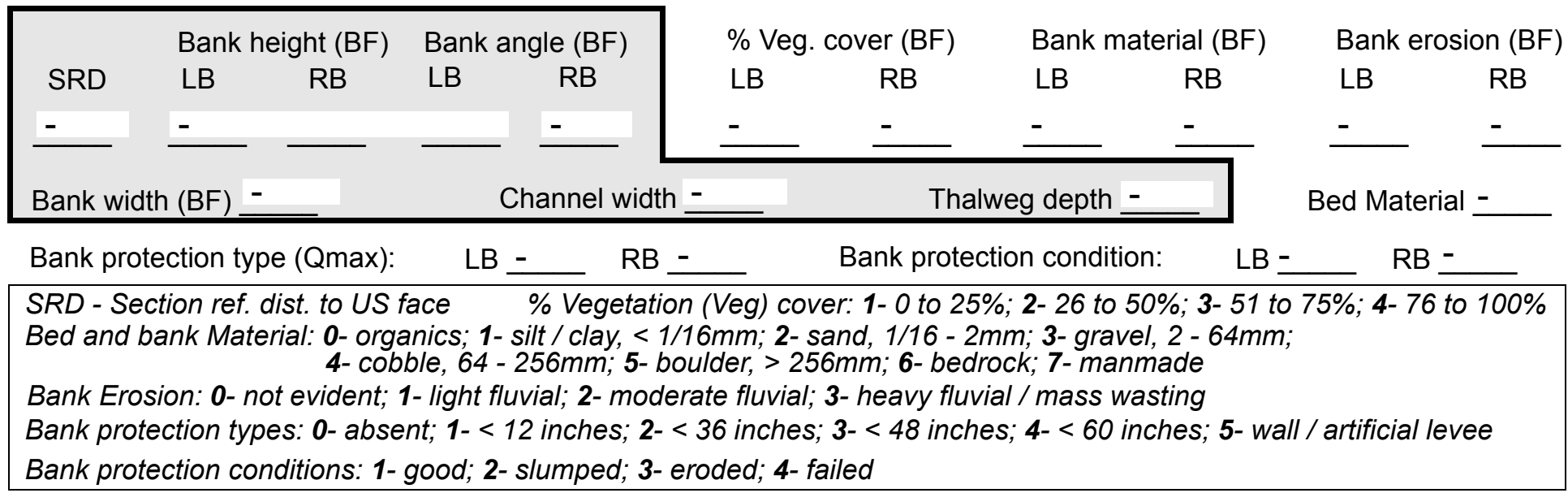

Comments (eg. bank material variation, minor inflows, protection extent, etc.):

$-$

$-$

$-$

$-$

$-$

$-$

$-$

$-$

$-$

$-$

101. Is a drop structure present? _ ( $Y$ or $N$, if $N$ type ctrl-n ds) 102. Distance: ___ feet
103. Drop: - feet
104. Structure material: -
(1- steel sheet pile; 2- wood pile; 3- concrete; 4- other)

105. Drop structure comments (eg. downstream scour depth): 
106. Point/Side bar present? (Y or $N$. if $N$ type ctrl-n pb)Mid-bar distance:

Mid-bar width: -

Point bar extent: feet -

(US, UB, DS) to feet (US, UB, DS) positioned $\%$ LB to $\% \mathrm{RB}$ Material:

Point or side bar comments (Circle Point or Side; note additional bars, material variation, status, etc.):

S a cut-bank present? $\mathbf{N}$ (Y or if $N$ type ctrl-n cb) Where? $\underline{\mathbf{O}}$ (LB or RB) Mid-bank distance: PIE Cut bank extent: $\underline{\mathbf{R S}}$ feet __ (US, UB, DS) to feet __ (US, UB, DS)

Bank damage: (1- eroded and/or creep; 2- slip failure; 3- block failure)

Cut bank comments (eg. additional cut banks, protection condition, etc.):

Is channel scour present? ( $Y$ or if $N$ type ctrl-n $c s)$

Mid-scour distance: 1 Scour dimensions: Length 1 Width 7 Depth: 7

Positioned 0 \%LB to $\mathbf{0}$ $\% \mathrm{RB}$ Scour comments (eg. additional scour areas, local scouring process, etc.): 54

2

3

3

Are there major confluences? 1 ( $Y$ or if $N$ type ctrl-n $m c)$ How many? Ban Confluence 1: Distance ks Enters on are ( $L B$ or $R B)$ Type $10 \mathrm{ft}$ (1- perennial; 2- ephemeral) Confluence 2: Distance high Enters on con- (LB or RB) Type cret (1-perennial; 2- ephemeral) Confluence comments (eg. confluence name):

e walls that extend about $130 \mathrm{ft}$ downstream from the bridge on both banks (including the wingwalls).

\section{F. Geomorphic Channel Assessment}

107. Stage of reach evolution

1- Constructed

2- Stable

3- Aggraded

4- Degraded

5- Laterally unstable

6- Vertically and laterally unstable 
108. Evolution comments (Channel evolution not considering bridge effects; See HEC-20, Figure 1 for geomorphic descriptors): 


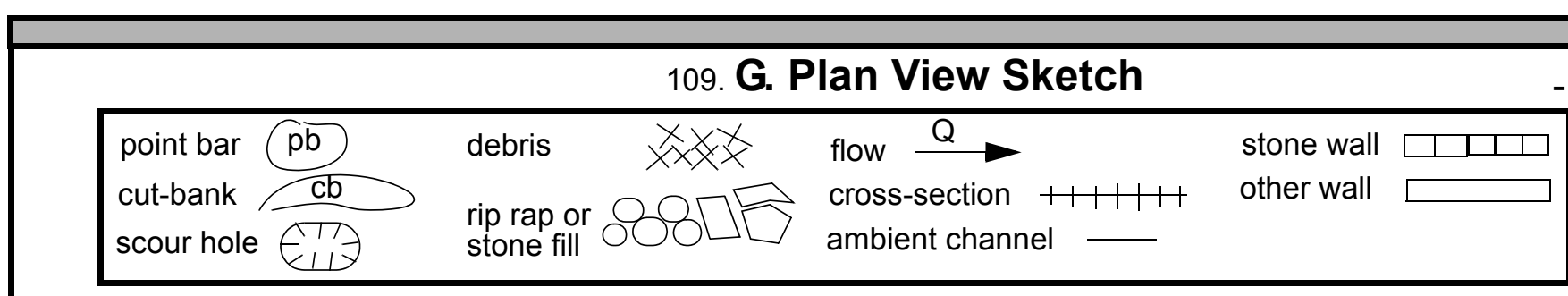


APPENDIX F:

SCOUR COMPUTATIONS 


\begin{tabular}{|c|c|c|c|}
\hline Structure Number: WODSTH00050071 & & Town: & WOODSTOCK \\
\hline Road Number: & & County: & WINDSOR \\
\hline Stream: KEDRON BROOK & & & \\
\hline Initials SAO & Checked: & MAI & \\
\hline alysis of contraction scour, li & d or & $r$ & \\
\hline $\begin{array}{l}\text { Critical Velocity of Bed Material } \\
\text { VC=11.21*Y1^0.1667*D50^0.33 with } \\
\text { (Richardson and others, 1995, p. } 2\end{array}$ & $\begin{array}{l}\text { converted } \\
=2.65 \\
\text { eq. } 16)\end{array}$ & to Eng & sh units) \\
\hline Approach Section & & & \\
\hline Characteristic & $100 \mathrm{yr}$ & $500 \mathrm{yr}$ & other $\mathrm{Q}$ \\
\hline Total discharge, cfs & 3400 & 4400 & 2500 \\
\hline Main Channel Area, ft2 & 601 & 622 & 441 \\
\hline Left overbank area, ft2 & 1192 & 1296 & 655 \\
\hline Right overbank area, ft2 & 547 & 627 & 91 \\
\hline Top width main channel, ft & 41 & 41 & 41 \\
\hline Top width L overbank, ft & 196 & 213 & 102 \\
\hline Top width $\mathrm{R}$ overbank, ft & 157 & 157 & 66 \\
\hline D50 of channel, ft & 0.368 & 0.368 & 0.368 \\
\hline D50 left overbank, ft & -- & -- & -- \\
\hline D50 right overbank, ft & -- & -- & -- \\
\hline Y1, average depth, MC, ft & 14.7 & 15.2 & 10.8 \\
\hline Y1, average depth, LOB, ft & 6.1 & 6.1 & 6.4 \\
\hline Y1, average depth, ROB, ft & 3.5 & 4.0 & 1.4 \\
\hline Total conveyance, approach & 229918 & 253014 & 117334 \\
\hline Conveyance, main channel & 105574 & 111829 & 62958 \\
\hline Conveyance, LOB & 90363 & 98631 & 51346 \\
\hline Conveyance, ROB & 33982 & 42554 & 3029 \\
\hline Percent discrepancy, conveyance & -0.0004 & 0.0000 & 0.0009 \\
\hline Qm, discharge, MC, cfs & 1561.2 & 1944.7 & 1341.4 \\
\hline Q1, discharge, LOB, cfs & 1336.3 & 1715.2 & 1094.0 \\
\hline Qr, discharge, ROB, cfs & 502.5 & 740.0 & 64.5 \\
\hline Vm, mean velocity $\mathrm{MC}$, ft/s & 2.6 & 3.1 & 3.0 \\
\hline Vl, mean velocity, LOB, ft/s & 1.1 & 1.3 & 1.7 \\
\hline Vr, mean velocity, $\mathrm{ROB}, \mathrm{ft} / \mathrm{s}$ & 0.9 & 1.2 & 0.7 \\
\hline Vc-m, crit. velocity, MC, ft/s & 12.6 & 12.6 & 11.9 \\
\hline $\mathrm{Vc}-1$, crit. velocity, LOB, ft/s & ERR & ERR & ERR \\
\hline Vc-r, crit. velocity, ROB, ft/s & ERR & ERR & ERR \\
\hline Results & & & \\
\hline Live-bed(1) or Clear-Water (0) Cont & action $\mathrm{S}$ & our? & \\
\hline Main Channel & 0 & 0 & 0 \\
\hline Left Overbank & $\mathrm{N} / \mathrm{A}$ & $\mathrm{N} / \mathrm{A}$ & $\mathrm{N} / \mathrm{A}$ \\
\hline Right Overbank & $\mathrm{N} / \mathrm{A}$ & $\mathrm{N} / \mathrm{A}$ & $\mathrm{N} / \mathrm{A}$ \\
\hline
\end{tabular}


Clear water Contraction Scour in MAIN CHANNEL

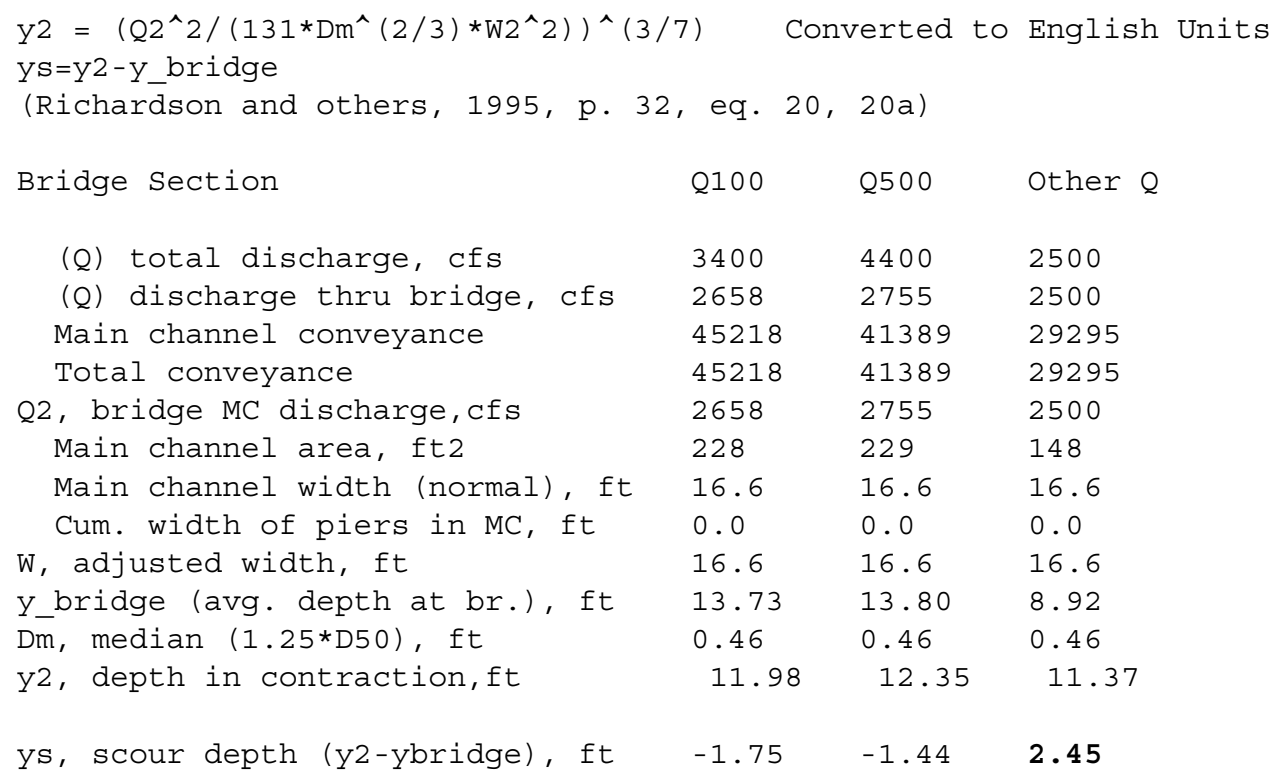

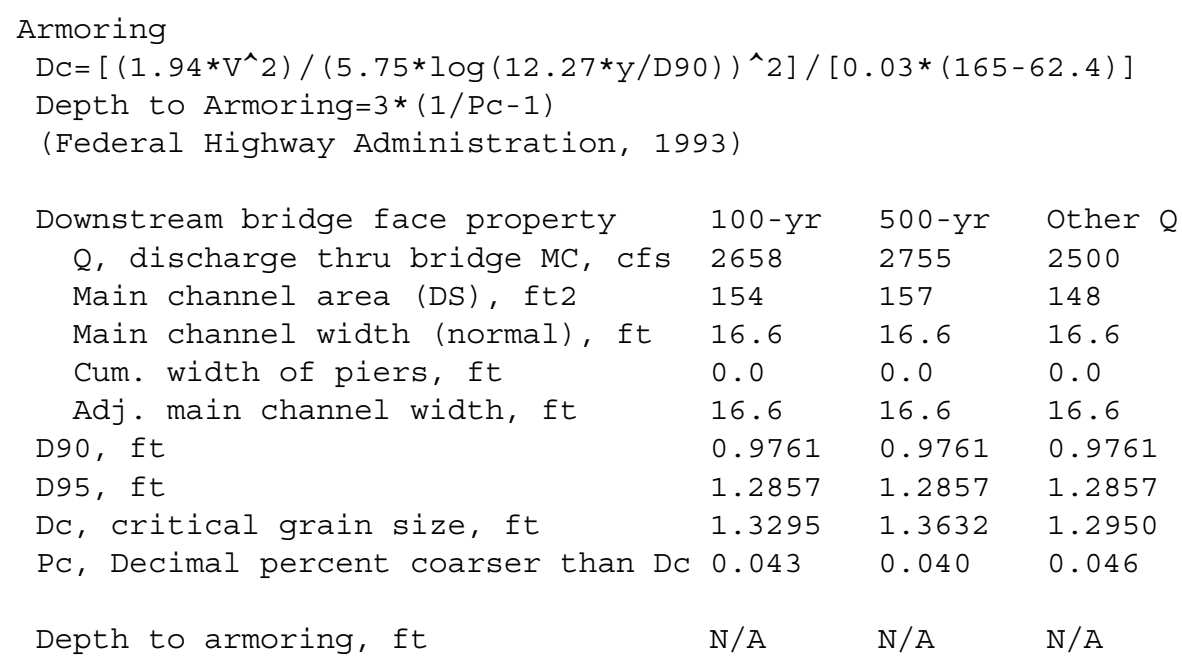




\begin{tabular}{|c|c|c|c|c|}
\hline \multicolumn{5}{|c|}{$\begin{array}{l}\text { Umbrell pressure flow equation } \\
(\mathrm{Hb}+\mathrm{Ys}) / \mathrm{ya}=1.1021 *[(1-\mathrm{w} / \mathrm{ya}) *(\mathrm{Va} / \mathrm{Vc})]^{\wedge} 0.6031 \\
\text { (Richardson and other, 1995, p. 144-146) }\end{array}$} \\
\hline & Q100 & Q500 & OtherQ & \\
\hline Q, total, cfs & 3400 & 4400 & 2500 & \\
\hline Q, thru bridge $\mathrm{MC}$, cfs & 2658 & 2755 & 2500 & \\
\hline Vc, critical velocity, ft/s & 12.57 & 12.64 & 11.94 & \\
\hline Va, velocity MC approach, ft/s & 2.60 & 3.13 & 3.04 & \\
\hline Main channel width (normal), ft & 16.6 & 16.6 & 16.6 & \\
\hline Cum. width of piers in MC, ft & 0.0 & 0.0 & 0.0 & \\
\hline w, adjusted width, ft & 16.6 & 16.6 & 16.6 & \\
\hline qbr, unit discharge, ft2/s & 160.1 & 166.0 & 150.6 & \\
\hline Area of full opening, ft2 & 228.0 & 229.0 & 148.0 & \\
\hline $\mathrm{Hb}$, depth of full opening, ft & 13.73 & 13.80 & 8.92 & \\
\hline Fr, Froude number, bridge MC & 0.66 & 0.68 & 0 & \\
\hline Cf, Fr correction factor $(<=1.0)$ & 1.00 & 1.00 & 0.00 & \\
\hline **Area at downstream face, ft2 & 154 & 157 & $\mathrm{~N} / \mathrm{A}$ & \\
\hline **Hb, depth at downstream face, ft & 9.28 & 9.46 & $\mathrm{~N} / \mathrm{A}$ & \\
\hline$\star *$ Fr, Froude number at DS face & 1.00 & 1.01 & ERR & \\
\hline$* * C f$, for downstream face $(<=1.0)$ & 1.00 & 1.00 & $\mathrm{~N} / \mathrm{A}$ & \\
\hline Elevation of Low steel, ft & 497.48 & 497.48 & 0 & \\
\hline Elevation of Bed, ft & 483.75 & 483.68 & -8.92 & \\
\hline Elevation of Approach, ft & 501.35 & 501.86 & 0 & \\
\hline Friction loss, approach, ft & 0 & 0.01 & 0 & \\
\hline Elevation of WS immediately US, ft & 501.35 & 501.85 & 0.00 & \\
\hline ya, depth immediately US, ft & 17.60 & 18.17 & 8.92 & \\
\hline Mean elevation of deck, ft & 500.42 & 500.42 & 0 & \\
\hline$w$, depth of overflow, ft $(>=0)$ & 0.93 & 1.43 & 0.00 & \\
\hline Cc, vert contrac correction $(<=1.0)$ & 0.95 & 0.95 & 1.00 & \\
\hline$* * C c$, for downstream face $(<=1.0)$ & 0.79 & 0.812686 & ERR & \\
\hline Ys, scour w/Chang equation, ft & -0.36 & -0.01 & $\mathrm{~N} / \mathrm{A}$ & \\
\hline Ys, scour w/Umbrell equation, ft & -6.48 & -5.59 & $\mathrm{~N} / \mathrm{A}$ & \\
\hline
\end{tabular}




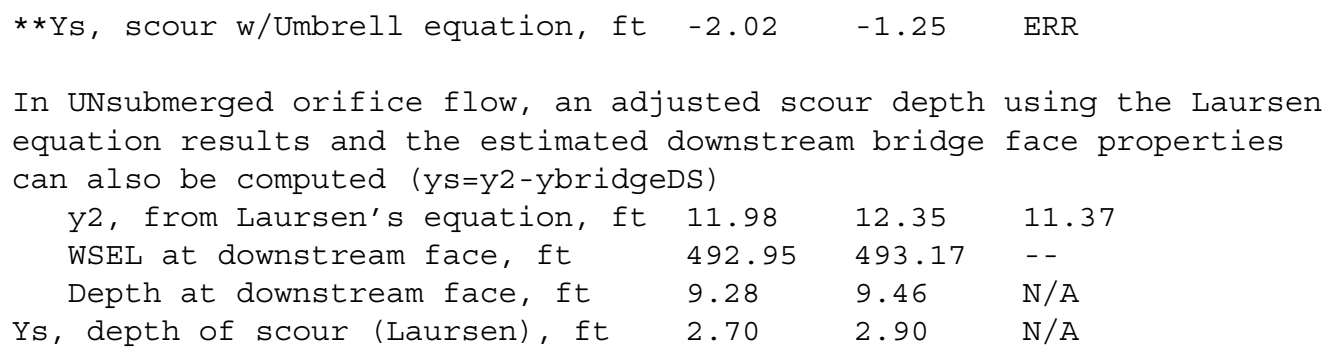

Abutment scour

Froehlich's Abutment Scour

$\mathrm{Ys} / \mathrm{Y} 1=2.27 * \mathrm{~K} 1 * \mathrm{~K} 2 *\left(\mathrm{a}^{\prime} / \mathrm{Y} 1\right)^{\wedge} 0.43 * \mathrm{Fr} 1^{\wedge} 0.61+1$

(Richardson and others, 1995, p. 48, eq. 28)

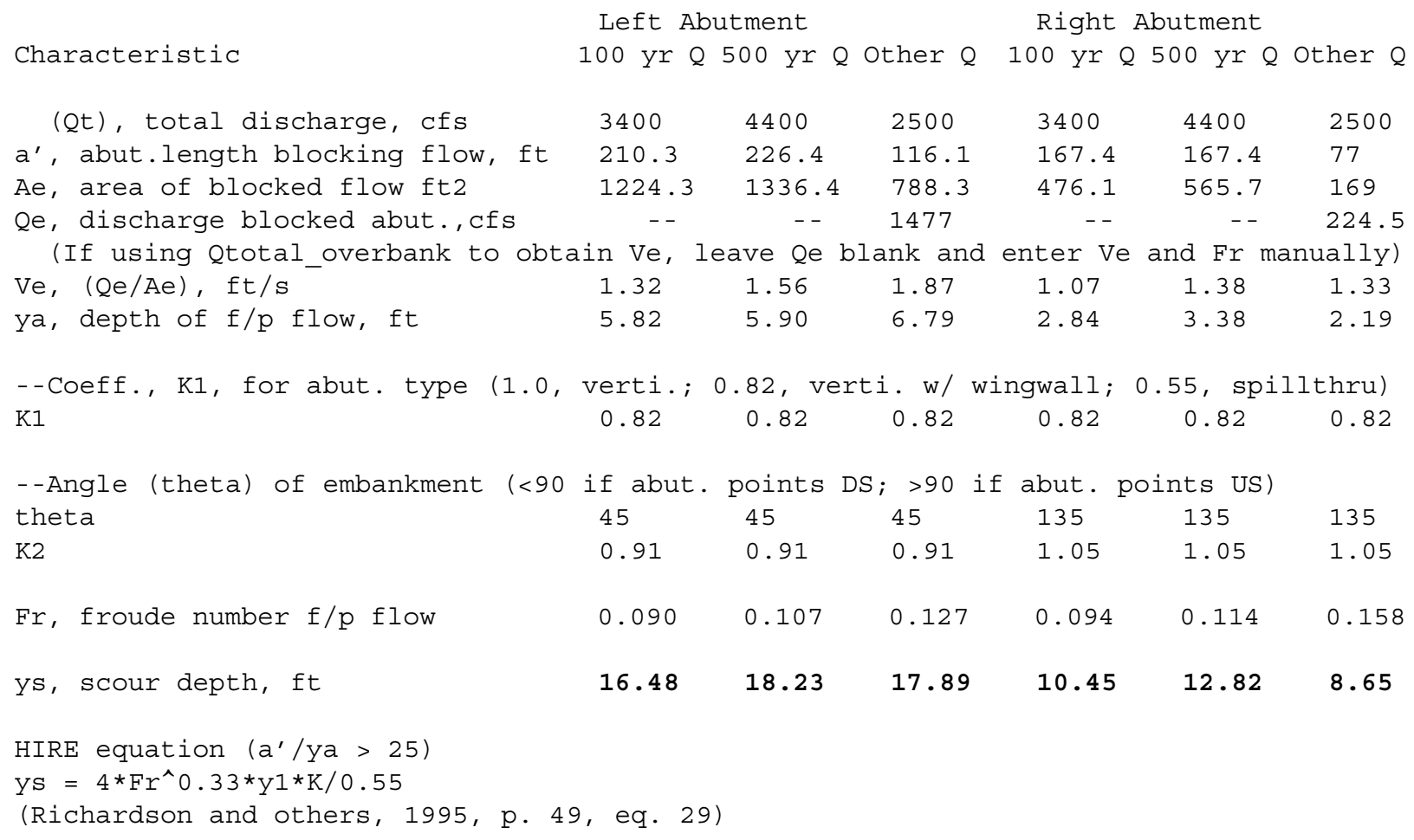




\begin{tabular}{|c|c|c|c|c|c|c|}
\hline$a^{\prime}$ (abut length blocked, ft) & 210.3 & 226.4 & 116.1 & 167.4 & 167.4 & 77 \\
\hline y1 (depth f/p flow, ft) & 5.82 & 5.90 & 6.79 & 2.84 & 3.38 & 2.19 \\
\hline$a^{\prime} / y^{1}$ & 36.12 & 38.35 & 17.10 & 58.86 & 49.54 & 35.08 \\
\hline Skew correction (p. 49, fig. 16) & 0.80 & 0.80 & 0.80 & 1.10 & 1.10 & 1.10 \\
\hline Froude no. f/p flow & 0.09 & 0.11 & 0.13 & 0.09 & 0.11 & 0.16 \\
\hline $\begin{array}{c}\text { Ys w/ corr. factor K1/0.55: } \\
\text { vertical }\end{array}$ & 15.30 & 16.43 & ERR & 10.43 & 13.20 & 9.55 \\
\hline vertical w/ ww's & 12.55 & 13.47 & ERR & 8.55 & 10.83 & 7.83 \\
\hline spill-through & 8.42 & 9.03 & ERR & 5.73 & 7.26 & 5.25 \\
\hline Abutment riprap Sizing & & & & & & \\
\hline Isbash Relationship & & & & & & \\
\hline $\begin{array}{l}\mathrm{D} 50=\mathrm{Y}^{*} \mathrm{~K} * \mathrm{Fr} \mathrm{r}^{\wedge} 2 /(\mathrm{Ss}-1) \text { and } \mathrm{D} 50=\mathrm{Y} * \mathrm{~K} *( \\
\text { (Richardson and others, } 1995, \mathrm{p} 11\end{array}$ & $\begin{array}{l}\wedge \\
2) \wedge 0.1 \\
\text { eq. } 81\end{array}$ & $(S s-1)$ & & & & \\
\hline Characteristic & Q100 & Q500 & Other $Q$ & Q100 & Q500 & Other $\mathrm{Q}$ \\
\hline Fr, Froude Number & 1 & 1 & 1 & 1 & 1 & 1 \\
\hline$y$, depth of flow in bridge, ft & 9.28 & 9.46 & 8.92 & 9.28 & 9.46 & 8.92 \\
\hline Median Stone Diamete & $:$ left & outment & & right & abutment, & ft \\
\hline Fr $<=0.8$ (vertical abut.) & ERR & ERR & ERR & ERR & ERR & ERR \\
\hline Fr>0.8 (vertical abut.) & 3.88 & 3.96 & 3.73 & 3.88 & 3.96 & 3.73 \\
\hline
\end{tabular}

